\title{
The Evolution of Property Rights: State Law or Informal Norms?
}

\author{
Ryan Bubb New York University
}

\begin{abstract}
This paper investigates the factors that have shaped the evolution of property rights institutions. Using a regression discontinuity design, I show that the divergent state laws of Ghana and Côte d'Ivoire have had little effect on de facto property rights institutions. In contrast, the data show that these states' laws and policies have had large impacts on other economic outcomes. Furthermore, I show that part of the substantial within-country variation in property rights institutions is explained by economic factors. Areas that are more suitable for growing cocoa have a greater prevalence of land transfer rights. My findings highlight the importance of nonstate sources of norms and show that these norms do, to some extent, evolve to accommodate the changing needs of society.
\end{abstract}

\section{Introduction}

Where do property rights come from? Some accounts of the development of property rights accord the state a central role (for example, North 1981). Moreover, a growing literature examining the effects of institutions on long-run development has largely focused on institutional variation mediated by states and used cross-country comparisons. For example, Acemoglu, Johnson, and Rob-

Financial support for this research was generously provided by the Hewlett Foundation and the John M. Olin Center for Law, Economics, and Business at Harvard Law School. I am grateful to an anonymous referee, Sam Peltzman, Hunt Allcott, Ernest Aryeetey, Ahbijit Banerjee, Robert Bates, Harold Demsetz, Esther Duflo, Erica Field, Ed Glaeser, Claudia Goldin, Oliver Hart, Daniel Ho, Richard Hornbeck, Nahomi Ichino, Lakshmi Iyer, Louis Kaplow, Michael Kremer, Sendhil Mullainathan, Nathan Nunn, Rohini Pande, James Robinson, Matthias Schundeln, Andrei Shleifer, Henry Smith, Chris Udry, Noam Yuchtman, and seminar participants at the Conference on Empirical Legal Studies, Harvard Law School, New York University School of Law, the Northeastern Universities Development Consortium Conference, Northwestern University Law School, Rice University, the Stanford-Yale Junior Faculty Forum, the University of California, Berkeley, the University of Houston, and the University of Toronto Faculty of Law for helpful comments and discussions. Dan Svirsky provided outstanding research assistance. All remaining errors are my own.

[Journal of Law and Economics, vol. 56 (August 2013)]

(C) 2013 by The University of Chicago. All rights reserved. 0022-2186/2013/5603-0018\$10.00 
inson (2001) and La Porta, Lopez-de-Silanes, and Shleifer (2008) provide strong evidence that the state institutions set up during the colonial period persisted and explain modern-day cross-national differences in economic performance.

However, there are alternative accounts of the determinants of property rights institutions in which the state is less central. Demsetz (1967), a seminal paper, argues that property rights tend to emerge when their benefits in terms of the internalization of externalities outweigh the costs of establishing and enforcing them. As an example he recounted the history of stateless societies in North America setting up private property in hunting grounds when the arrival of Europeans increased the value of animal fur. Moreover, a growing literature documents the importance of informal social norms (for example, Ellickson 1991; Posner 2000).

This paper investigates the factors that have shaped the evolution of property rights institutions. I first examine the impact of state law on the de facto institutions governing property in land. I use data from Ghana and Côte d'Ivoire, two neighboring states that have had very different state law on property. In particular, beginning with British rule in the colonial period, the Ghanaian state incorporated customary law on land, which limits the rights of households to alienate their land, into its common-law regime. In contrast, the French rulers of Côte d'Ivoire largely ignored customary institutions, declaring all unused land property of the state, and the postcolonial Ivorian state continued the policy of marginalizing customary institutions in the de jure legal regime.

National-level measures of property rights institutions in the two countries are consistent with the view that these differences in de jure legal institutions had large effects on de facto institutions: a much larger fraction of households in Côte d'Ivoire report the right to alienate their land than in Ghana. However, the two countries are different in ways other than their state institutions and policies, such as in geography, precolonial population density, and ethnic group composition. Comparisons at the national level cannot disentangle the causal effect of state institutions and policies from the effects of these other differences.

My empirical approach is to instead use household-level data in a regression discontinuity design that exploits the discontinuous change in state and de jure law at the international border. While areas of Ghana and Côte d'Ivoire far from the border are quite different, as one approaches the border between the two countries, the geography and precolonial ethnic groups and institutions on either side converge. As long as other determinants of institutions vary continuously at the border, any differences in property rights institutions in the areas just on either side of the border must result from the cumulative effects of state policies and de jure law from the time the border was drawn to the present rather than from preexisting differences.

I find that, despite very different de jure legal regimes, measures of de facto property rights in land are remarkably continuous at the border. Households just on either side of the border report similar prevalences of rights to rent out their land and to sell their land. These results provide evidence that formal state 
law and policy have had a limited effect on property rights institutions and that instead nonstate sources of norms shape the de facto rules governing property in land.

In contrast, the data show that service provision by states and agricultural policy play important roles in economic outcomes. Measures of human capital investment jump discontinuously at the border, which implies that Ghana's greater expenditure on schooling has raised human capital in rural areas relative to that in Côte d'Ivoire. Furthermore, each state's agricultural policies have had a profound effect on crop choices: coffee production jumps from a low level in Ghana to a high level in Côte d'Ivoire, likely as a result of the long involvement of the Ivorian state in regulating exports.

Thus, it appears that states are not completely ineffectual in this context but rather are ineffectual at influencing certain types of institutions. I hypothesize that the patterns in the data are explained by conflicts between national and local elites and the relative capacity of national elites. Herbst (2000) argues that states in Africa developed a low capacity to control their hinterland areas because of a challenging geographic environment and limited external threats. For policies in which the interests of local and national elites conflict, the outcome depends on how difficult the policy is for the state to implement and on the state's capacity. Property in land is a deeply rooted local institution in which local elites have a vested interest (Goldstein and Udry 2008). Moreover, state-led reforms of these institutions require a large administrative apparatus in the hinterlands. Hence, we observe no effect of state policy on de facto property rights institutions. In contrast, no conflict existed over educational policy, and implementation of national export crop policies required mainly just control over the ports. Hence, we observe effective state policy in those domains.

The low capacity of African states may well explain part of the continent's abysmal growth record (Easterly and Levine 1997). But my results suggest that within sub-Saharan Africa, where states have short histories and limited capacity, variations in de facto property rights institutions may have little to do with states and de jure law.

A limitation of my regression discontinuity research design is that it allows me to estimate only the local average treatment effect of states at the border, a rural and relatively remote area. Of course, most agricultural land in Africa is in rural areas remote from the national capital, which makes this an estimand of significant interest.

Several recent studies have similarly exploited jurisdictional boundaries to investigate the role of formal institutions and states in Africa, including Berger (2009), Cogneau and Moradi (2011), and Cogneau, Mesple-Somps, and Spielvogel (2012). Most relevant to the present study is Michalopoulos and Papaioannou (2013), in which the authors use light density to measure economic development and find that within ethnic groups, state-level institutions have no effect on economic performance. My results significantly qualify those findings. In particular, my findings of strong effects of the state on human capital and 
production choices demonstrate that while African states may not drive the part of the (within-Africa) variation in economic performance that is measured by light density, they do matter for important economic outcomes.

While states play a limited role in property rights institutions in this context, there is substantial variation in property rights institutions within Ghana and Côte d'Ivoire. I show that part of this within-country institutional variation is explained by economic factors, as Demsetz (1967) hypothesizes. In particular, areas that are more suitable for growing cocoa, an important export crop in the region, have a greater prevalence of land transfer rights, which provides evidence that the commercialization of agriculture has led to more individualized property rights institutions. My results thus provide support for the view of Easterly (2008) that bottom-up institutional evolution is more important than state-led reforms in determining property rights institutions in Africa.

The paper proceeds as follows. In Section 2, I describe both the indigenous property rights institutions in West Africa and the de jure legal regimes in Ghana and Côte d'Ivoire. In Section 3, I present regression discontinuity estimates of the effect of those state-level institutions on de facto property rights institutions and on economic outcomes. In Section 4, I turn to explaining the institutional variation within Ghana, using cocoa suitability to test the Demsetzian hypothesis. Section 5 concludes.

\section{Background}

\subsection{Indigenous Property Rights Institutions in West Africa}

While there is considerable variation, both over time and across space, the indigenous property rights institutions in West Africa typically have a communal element in the sense that individual households have rights to use land that are derivative of the rights of some broader social group, and a representative of the social group (for example, a chief or lineage head) regulates access to and transfers of land. Here I describe the indigenous institutions of the Ashanti people of Ghana, which are particularly well documented (see Rattray 1923, 1929; Busia 1951; Asante 1964; Wilks 1993; Austin 2004). The Ashanti are part of the larger Akan group, which is the major ethnic group that spans the border between Ghana and Côte d'Ivoire, and thus their institutions are of particular relevance given my empirical strategy. It is important to note, however, that the Ashanti had a relatively centralized state, and the property rights institutions of less centralized precolonial polities likely provided somewhat stronger rights over particular parcels of land to individual households (Asante 1964).

Among the Ashanti, land had a spiritual significance-it was regarded as belonging to the ancestors of a community, from whom the living inherited the right to use the land (Busia 1951, p. 42). Individual Ashanti households thus did not own their land in the sense of an estate in fee simple under modern common law. Rather, the land was vested in the community, with the chief acting 
as a custodian. The community was symbolized by a ceremonial stool on which the chief sat. Hence, "[i]n any Ashanti village the inquirer was informed, 'The land belongs to the stool,' or 'The land belongs to the chief.' Further investigation revealed that both expressions meant the same thing: 'The land belongs to the ancestors"” (Busia 1951, p. 44).

Subjects of a stool claimed use rights to land through their matrilineage ( $a b u$ sua), which is an extended family group. Members of such a lineage could acquire use rights for the lineage simply by investing their labor in clearing and cultivating unclaimed land within the stool boundaries. The head of each lineage was in turn responsible for allocating use rights among its members.

Households individually owned the crops that they grew on the land they cultivated, but their rights over the land did not include the full bundle of rights we typically call ownership. Hence, we have the Ashanti maxim afuo mu ys me des, asase yz shene des (the farm is my property, the land is the chief's) (Rattray 1929; Wilks 1993). Individual households generally could not alienate their use rights to land to an outsider, at least not without obtaining permission from their lineage and chief (Rattray 1929, p. 363). Moreover, when a household stopped cultivating land, the land would generally revert back to the community, and use rights to it could be acquired by another household. A subject's use rights could be passed on to his heirs upon his death. It is important to note, however, that heirs were traced matrilineally, so that a man could not pass on property to his children but rather passed it to his brothers or nephews. ${ }^{1}$

The chief's role as custodian of the land included settling disputes between lineages, reallocating land among lineages, and superintending transfers of land within the community. With appropriate consent from elders of the community, the chief could sell the community's land to outsiders. Furthermore, "strangers" who migrated outside their home communities had to bargain with the chief of their host community and typically pay some form of regular tribute in exchange for the right to use land. The community retained a reversionary interest in the land in the case that a stranger settler died without heirs (Rattray 1923, p. 232).

This system of property rights in land may result in certain inefficiencies. For example, investments in land may be lower because individual households would be unlikely to reap the full benefits of their investment (Besley 1995; Goldstein and Udry 2008). Moreover, restraints on alienation may prevent the highest value user from acquiring the land and, in the presence of other factor market imperfections, result in an inefficient allocation of labor to land.

\subsection{Cocoa and the Evolution of Property Rights}

There is general consensus that property rights in land in West Africa evolved to become more individualized over the course of the twentieth century, giving greater rights to the individual cultivating household and less authority to extended family groups and chiefs. A commonly cited factor driving the individ-

\footnotetext{
${ }^{1}$ A man's sons are members of their mother's abusua, not their father's.
} 
ualization of property rights in Ghana and Côte d'Ivoire is the adoption of cash crops, most importantly cocoa (Bruce 1988). Cocoa production was adopted around the turn of the twentieth century, and Ghana and Côte d'Ivoire quickly became two of the world's largest producers. Qualitative case studies suggest that the introduction of cocoa led to an individualization of property rights in land.

Hill (1963) provides an influential account of this process in southern Ghana. In the 1890s, farmers from the Akwapim region began adopting cocoa. Local land suitable for cocoa production was soon exhausted, and these pioneering cocoa farmers migrated north into the forest belt of Akyem Abuakwa in search of more land. This area was largely uncultivated but fell under the authority of local chiefs. The migrant farmers bargained with those chiefs, buying large tracts of land outright, and by about 1918 much of the forest land of southern Akyem Abuakwa had been sold to migrant farmers for cocoa production. The purchasers were still subject to claims of their extended family over their self-acquired land. But Hill (1963) argues that increasingly these migrant cocoa farmers were able to keep their land as their own individual property and to bequeath and sell it without seeking permission from their extended family. Hill (1963, p. 132) quotes the chief justice of Nigeria, whose country experienced a similar transformation: "The cocoa boom led to large numbers of individuals amassing wealth by their own efforts and purchasing property for themselves with the proceeds; so that the presumption in favor of all property being family property is not nearly so strong today as it was thirty years ago."

The idea that cocoa production led to individualization of property rights is an application of the Demsetzian theory of property rights. In a classic contribution, Demsetz (1967, p. 350) argues that "the emergence of new property rights takes place in response to the desires of the interacting persons for adjustment to new benefit-cost possibilities. . . . [P] roperty rights develop to internalize externalities when the gains of internalization become larger than the cost of internalization." Platteau $(1996,2000)$ labels this theory the evolutionary theory of land rights-institutions evolve in response to demand for new institutions as economic conditions change. Demsetz's hypothesis that property rights institutions tend to evolve efficiently has been applied by examining various economic factors that might affect the costs and benefits of more individualized property rights institutions. In this vein, North and Thomas (1973) argue that increasing population density explains the move toward individual ownership of land in Europe between 1000 and 1300. Other accounts of the evolution of property rights in land that focus on population density include Lewis (1955), Boserup (1965), Hopkins (1973), Ault and Rutman (1979), and Fenske (2012).

Applied to the commercialization of agriculture, a Demsetzian theory would be that as farmers move from subsistence production to producing for the market, the size of the distortion caused by communal property rights gets larger. If there is some fixed cost to changing institutions, as in Mulligan and Shleifer 
(2005), then the introduction of export crops could induce institutional change by causing the benefits of such change to exceed the costs.

However, the existing quantitative evidence on the effect of commercialization of agriculture on property rights is weak. In the leading study, Migot-Adholla et al. (1991) compare three regions of Rwanda and find that transfer rights in land are most prevalent in the region with the greatest degree of commercialization of agricultural production. In addition to a small sample size, the study is plagued by a reverse-causality problem: having more individualized land rights may encourage cash crop adoption.

\subsection{De Jure Property Law in Ghana and Côte d'Ivoire}

Another potential factor in shaping the evolution of property rights is statelevel policy and de jure property law. The African states that correspond to present-day borders are relatively recent creations. Many areas of precolonial Africa lacked any centralized political institutions like those of the modern state, and the precolonial states that did exist were largely based on different borders and institutional structures than those that emerged under colonialism. The colonial period was brief. The colonial powers began demarcating and claiming territory in Africa in the scramble following the Berlin Conference of 1885 . During this period, the modern borders of Ghana and Côte d'Ivoire were established. Beginning in 1957 with Ghana, African colonies became independent states with few changes in boundaries. Herbst (2000) argues that both colonial and postcolonial states in Africa faced a challenging geographic environment of low population density and limited external threats such that the costs of effectively controlling their hinterland areas exceeded the benefits, which led to low-capacity states.

Nonetheless, it has long been argued that differences in the ruling strategies of the French and British had persistent effects on African states in the postindependence period (Crowder 1964). Furthermore, the broader literature on institutions and development focuses on state-mediated variations in institutions. Most notably, perhaps, La Porta, Lopez-de-Silanes, and Shleifer (2008) and Acemoglu, Johnson, and Robinson (2001) argue that the state institutions set up during the colonial period had long-lasting economic consequences. The former focus on the identity of the colonizer, contrasting the legal systems transplanted by the French and British to their colonial possessions. The latter argue that the conditions facing settlers shaped the nature of institutions set up by the colonial powers. Both argue that these colonial shocks to state institutions had persistent economic effects.

Some scholars view the state's role in property rights in sub-Saharan Africa as central. For example, Boone (2007, p. 560) argues that "the role of the state in defining property rights, especially rural property rights, has been decisive in shaping the locus and character of political authority in modern Africa." She argues that African state property regimes generally fall into one of two categories. 
"Communal regimes," like the one in Ghana, act to create or "uphold" communal land tenure. In contrast, "user rights regimes" like that of Côte d'Ivoire "used the powers of the modern state to challenge pre-existing . . . land allocation authorities by standing behind and enforcing the land claims of "whoever farms the land"' (Boone 2007, p. 564). The contrast between the state policies and de jure law of Ghana and Côte d'Ivoire thus arguably typifies the variation in statelevel de jure property regimes in Africa more generally. I describe each in turn.

\subsubsection{Ghana}

Ghana was colonized by the British, who imported their common-law legal institutions. The British recognized indigenous customary law in their courts in Ghana-respect for custom is a hallmark of the common-law approach-beginning with the Supreme Courts Ordinance of $1876 .^{2}$

Furthermore, the British delegated substantial authority to indigenous elites under their indirect-rule policy. The putative goal of the British colonial rulers was, as one colonial administrator put it, to "grant to Africa the benefits of Western civilization without disrupting the social institutions of the African people" (Hailey 1957, p. 201). Notably, under the Native Jurisdiction Ordinance of 1883, chiefs were authorized to create "native tribunals" with jurisdiction over, inter alia, "all disputes relating to the ownership or possession of lands held under native tenure" (Native Jurisdiction Ordinance, sec. 11 [1883], in Griffith [1898, 1:392-93]). Firmin-Sellers (1996) and Berry (2000) argue that the incorporation of chiefs as agents of the colonial state served to increase the power of chiefs with respect to the allocation of land.

British courts, when hearing appeals from native tribunals, applied the idea that individual ownership was foreign to West Africa. In an opinion issued in 1921, the Privy Council endorsed the view expressed by Chief Justice Rayner: "The next fact which it is important to bear in mind in order to understand the native land law is that the notion of individual ownership is quite foreign to native ideas. Land belongs to the community, the village or the family, never to the individual. All the members of the community, village, or family have an equal right to the land, but in every case the Chief or Headman of the community or village, or head of the family, has charge of the land, and in loose mode of speech is sometimes called the owner" (Tijani v. Secretary of Southern Nigeria, [1921] 2 A.C. 399, 404). This principle was subsequently applied in courts throughout British West Africa (Asante 1964, p. 857).

The colonial state deployed formal law to attempt to slow the individualization of property rights in Ghana. Firmin-Sellers (1996) recounts one such episode in Akyem Abuakwa. The sale of land by local divisional chiefs to migrant cocoa

\footnotetext{
${ }^{2}$ The ordinance provided that "[n] othing in this Ordinance shall deprive the Supreme Court of the right to observe . . . any law or custom existing in the Colony. . . . Such laws and customs shall be deemed applicable in causes and matters where the parties thereto are natives of the Colony, and particularly... in causes and matters relating . . . to the tenure and transfer of real and personal property" (Supreme Courts Ordinance, sec. 19 [1876], in Griffith [1898, 1:16]).
} 
farmers was seen by the paramount chief, Nana Ofori Atta, enstooled in 1918, as a significant threat to his own interests. In consultation with the British authorities, Ofori Atta drafted and ultimately had enacted the Akyem Abuakwa State Council Stool Lands Declaration of 1932, which asserted the paramount chief's right to approve all land sales in Akyem Abuakwa. Firmin-Sellers (1996, p. 64) argues that the British authorities supported Ofori Atta's attempt to defend the customary property system "in an effort to bolster the authority of the traditional chiefs through whom they governed."

After independence, the Ghanaian state continued to consider customary law part of the de jure law of Ghana. Article 40 of the 1960 Constitution of the Republic of Ghana included customary law, defined in section 18 of the Interpretation Act of 1960 as consisting of "rules of law which, by custom, are applicable to particular communities in Ghana," as part of the law of Ghana. Crook et al. (2007) argue that the formal incorporation of customary law into the law of Ghana has resulted in a highly legalized form of customary law, developed by formal judicial rulings with stare decisis effect, which then feeds back into the norms applied by (especially well educated) nonstate customary actors.

\subsubsection{Côte d'Ivoire}

The de jure property law of Côte d'Ivoire followed a markedly different path than that of Ghana. Côte d'Ivoire was colonized by the French, who took a decidedly more dismissive approach to customary law. ${ }^{3}$ At the outset of the colonial period, the French administration claimed state ownership of all land then unoccupied and uncultivated, which at that point was the vast majority of land in Côte d'Ivoire, and extinguished any customary claims (Decree of July 20, 1900). In 1932, the French administration defined the legal procedure for obtaining freehold land title, which required only evidence of active land use, thereby further moving the de jure regime away from customary norms (Decree of July 26, 1932). The French approach to property in land in Côte d'Ivoire was consistent with the French general direct-rule approach to colonial governance, which relied on putting French administrators in the hinterlands and suppressing indigenous elites (Suret-Canale 1971, pp. 71-83). Near the end of the colonial period, in 1955, the French government reversed its policy by renouncing state claims to uncultivated land, recognizing customary rights to land, and requiring concessionaires to seek waiver of rights by any customary claimants (Decree of May 20, 1955). However, this reversal was soon rescinded by the government of the newly independent Côte d'Ivoire in the Decree of March 20, 1967.

A key component of the economic policy of the ruling party after independence was to enhance the property rights of migrant settlers in order to promote agricultural development. Much as in Ghana, migrants played an important role in the adoption of tree crops such as cocoa and coffee in Côte d'Ivoire. However,

\footnotetext{
${ }^{3}$ The account that follows draws on Heath (1993).
} 
local customary authorities, instead of selling the land outright, gave migrants access to land through the tutorat institution, which limited the land rights of migrants and moreover required migrant settlers to pay large regular land fees in perpetuity (Chauveau and Colin 2010). Côte d'Ivoire's first president, Felix Houphouet-Boigny, intervened on behalf of these migrants to encourage additional settlement and development. Formally, he declared that "land belongs to the person who brings it into production, providing that exploitation rights have been formally registered" (Decree of March 20, 1967). The registration proviso of the decree, however, was unobserved, and the decree was used as justification for land claims based on simply clearing the land (Heath 1993, p. 32). Similarly, an Interior Ministry circular dated December 17, 1968, asserted that "the state is the owner of all unregistered land" and that "customary rights to land are abolished" (Heath 1993, p. 32). Chauveau and Colin (2010, pp. 90-91) argue that more important than these formal legal interventions in loosening customary authorities' claims over the settlers were state "interventions of a fundamentally political and clientelistic nature" aimed at inducing customary authorities to cede land ownership rights to settlers.

\subsubsection{Implications of De Jure Law for the Evolution of Property Rights}

In sum, the formal legal system of Ghana has historically supported customary law on land, while that of Côte d'Ivoire has undercut it. If formal law matters in this context, we would expect property rights to be more individualized in Côte d'Ivoire than in Ghana. And, indeed, scholars have argued that these differences in de jure law in Ghana and Côte d'Ivoire led to changes in the de facto property rights institutions, that is, the rules that in practice apply and constrain households in their use of and transactions in land. For example, Firmin-Sellers (2000, p. 256) argues that "French and British colonizers designed very different institutions to regulate their interaction with indigenous chiefs [in Côte d'Ivoire and Ghana]. . . . Consequently, these institutions yielded very different property rights systems and landholding patterns."

Firmin-Sellers (2000) goes on to argue that in Côte d'Ivoire, lineage heads became outright owners of land, unconstrained by chiefs, because of the undermining of chiefs by the French. In contrast, both commoners and the paramount chiefs whose authority over land extended over a large area in Ghana were empowered by the British, while local chiefs were marginalized. Crook et al. (2007) similarly argue that intervention by the two states has led to more individualized property rights in Côte d'Ivoire than in Ghana.

However, the fact that states in West Africa are generally young and weak casts doubt on the view that these state-level institutional differences have had a large impact on the de facto norms that shape decision making. Moreover, there is little existing quantitative evidence on the role of states and formal de jure law in affecting the de facto property rights institutions in West Africa. 


\section{The Effect of States and De Jure Property Law on De Facto Institutions}

\subsection{Data and Descriptive Statistics}

To investigate whether the differences in state-level institutions and de jure property law in Ghana and Côte d'Ivoire had a causal effect on the evolution of de facto property rights institutions, I use data from the first two surveys from the Living Standards Measurement Study (LSMS) run by the World Bank in Africa: the Côte d'Ivoire Living Standards Survey (CILSS) and the Ghana Living Standards Survey (GLSS). The CILSS, which ran from 1985 to 1988, was the first LSMS survey ever administered. Data for the GLSS rounds 1 and 2 were collected in 1987-88 and 1988-89, respectively, using a survey instrument nearly identical to the CILSS questionnaire. Each survey's questionnaire contains detailed questions on household composition, education, consumption, production, assets, and borrowing, as well as questions on households' perceptions of their rights to sell and rent out their land.

While these data were collected some 25 years ago, the process of institutional change is typically a relatively slow, long-term one, and hence the age of the data detract little from what they can reveal about the determinants of this longterm process. Moreover, and perhaps more important, the key advantage of these data is that they came from two largely identical large-scale household surveys run concurrently in Ghana and Côte d'Ivoire that included questions on property rights. They are thus uniquely suited to my regression discontinuity approach in investigating the role of states and de jure law.

Both surveys used a two-stage sampling design in which enumeration areas (EAs) were first randomly selected from a stratified list of populated places from the most recent national census, and then a sample of households was randomly selected from each selected EA. I determined the locations of the EAs using maps and data from the GEOnet Names Server. Figure 1 provides a map of the GLSS rounds 1 and 2 and CILSS EAs. More details on the sampling process are provided in the Appendix.

\subsubsection{Sample Selection and Descriptive Statistics}

I restrict the sample to GLSS and CILSS households that own agricultural land. I exclude households that rent in or sharecrop in all of the agricultural land they use. The reason is that, as I discuss below, I use household members' perceptions of their transfer rights as measures of de facto property rights institutions. Households generally cannot sell or sublease land that they rent. Were I to include tenant farmers in the sample, then it would appear that transfer rights are less prevalent in areas where there are more transfers through leasing.

Details of the variable construction and definitions are provided in Table A1. Table 1 provides descriptive statistics for the resulting sample from the two surveys. 


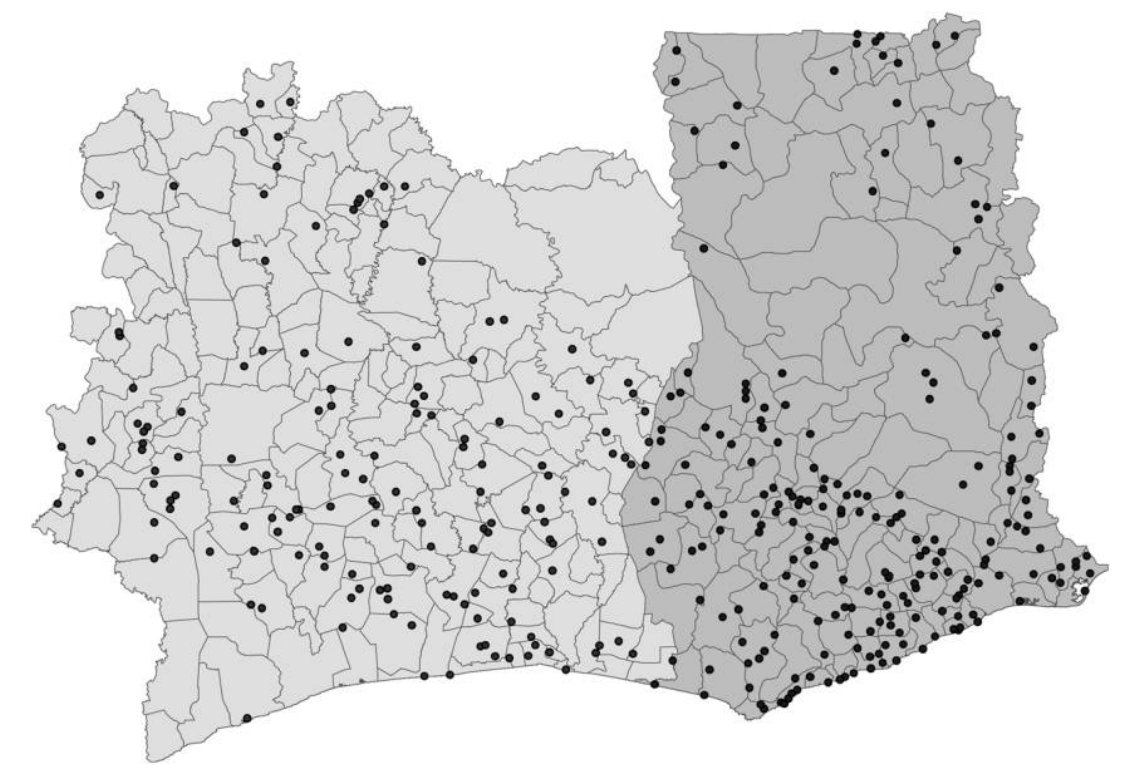

Figure 1. Ghana Living Standards Survey rounds 1 and 2 and Côte d'Ivoire Living Standards Survey enumeration areas.

\subsubsection{Measures of De Facto Property Rights Institutions}

I use household members' perceptions of their right to rent out and their right to sell their land as measures of de facto property rights institutions. This approach is commonly used in the literature on African property rights institutions. For example, Besley (1995) uses self-reported transfer rights in his study of the effect of property rights on investment incentives. He finds that an index of self-reported rights to sell, rent, gift, mortgage, pledge, and bequeath a field is associated with increased investments in the field.

The rationale for using transfer rights as a measure of property rights is threefold. First, the right to transfer use rights in land is itself an important right. It enables owners to realize the full value of their investments in land and, when other factor markets are imperfect, helps to efficiently allocate other factors, most importantly labor, to land.

Second, as discussed above, restrictions on transferring land are a feature of the customary property rights institutions in much of West Africa. Hence, the prevalence of transfer rights is a good measure of the degree to which institutions have evolved toward more individualized property rights.

Third, transfer rights are correlated with other aspects of property rights, for example, the right to continued exclusive use of the land even after fallowing it (Goldstein and Udry 2008). Table 2 provides the correlation matrix of the two 
Table 1

Sample Descriptive Statistics

\begin{tabular}{lcrr}
\hline Variable & Mean & SD & $N$ \\
\hline Ghana & .571 & .495 & 4,919 \\
Right to Rent out Land & .508 & .500 & 4,916 \\
Right to Sell Land & .311 & .463 & 4,818 \\
Rented out Land in Last 12 Months & .103 & .304 & 4,914 \\
Sold Land in Last 12 Months & .007 & .083 & 3,734 \\
Amount of Land Owned by the Household & 40.4 & 100 & 4,919 \\
Value of Land & $4,042,828$ & $38,648,143$ & 4,503 \\
Fraction of Land Fallow & .297 & .278 & 4,919 \\
Grows Cocoa & .347 & .476 & 4,919 \\
Grows Coffee & .205 & .404 & 4,919 \\
Grows Cocoa or Coffee & .414 & .493 & 4,919 \\
Household Head Male & .818 & .386 & 4,917 \\
Age of Household Head & 47.6 & 15.3 & 4,917 \\
Household Head Attended School & .376 & .484 & 4,916 \\
Household Head Literate & .298 & .457 & 4,916 \\
Household Head Numerate & .341 & .474 & 4,916 \\
Household Head Born Elsewhere & .373 & .484 & 4,915 \\
Distance to Border (kilometers) & 225 & 129 & 4,919 \\
\hline
\end{tabular}

Note. The sample is all households in the Ghana Living Standards Survey rounds 1 and 2 (1987-89) and the Côte d'Ivoire Living Standards Survey (1985-88) that owned agricultural land. The statistics are unweighted and describe the sample, not the population.

transfer rights measures - the right to rent out land and the right to sell landas well as an indicator for whether the household is currently renting out land and the fraction of the household's land that is currently left fallow. The pairwise correlation coefficients of these four variables are all positive and statistically significant.

To further validate the transfer rights measures, it is useful to verify that the measures correlate in expected ways with household characteristics. Table 3 presents household-level correlates of land transfer rights. It reports the results of regressions of Right to Rent out Land and Right to Sell Land on a set of household-level characteristics as well as EA fixed effects for the sample from the GLSS and CILSS samples.

One might expect that the right to rent out land is more valuable for households with a greater amount of land, given the need to attract labor to work the land. For both surveys and both transfer rights measures, households who own more land are indeed more likely to report the right to transfer their land. For example, a 10 percent increase in the amount of land the household owns is associated with about a 1-percentage-point increase in the probability that the household has the right to rent out its land in Ghana.

Three other household-level correlates of transfer rights are noteworthy. Households that grow cocoa or coffee are significantly more likely to report transfer rights in Ghana and the right to rent in Côte d'Ivoire. In Section 4, I 
Table 2

Land Rights Variables Correlation Matrix

\begin{tabular}{lcccc}
\hline & $\begin{array}{c}\text { Right to Rent } \\
\text { out Land }\end{array}$ & $\begin{array}{c}\text { Right to } \\
\text { Sell Land }\end{array}$ & $\begin{array}{c}\text { Rented out Land } \\
\text { in Last 12 Months }\end{array}$ & $\begin{array}{c}\text { Fraction of } \\
\text { Land Fallow }\end{array}$ \\
\hline Right to Rent out Land & 1.000 & & & \\
Right to Sell Land & $.433^{* *}$ & 1.000 & & \\
Rented out Land in Last 12 Months & $.334^{* *}$ & $.212^{* *}$ & 1.000 & \\
Fraction of Land Fallow & $.186^{* *}$ & $.179^{* *}$ & $.043^{*}$ & 1.000 \\
\hline
\end{tabular}

Note. The sample is all households in the Ghana Living Standards Survey rounds 1 and 2 (1987-89) and the Côte d'Ivoire Living Standards Survey (1985-88) that owned agricultural land.

* Significant at the .05 level.

** Significant at the .01 level.

use a geographic index that predicts cocoa production to investigate the effect of cocoa production on property rights.

Older household heads are more likely to report transfer rights in three of the four regressions. For example, a 10-year increase in age is associated with a 2-percentage-point increase in the probability that the household has the right to rent out its land in Côte d'Ivoire.

Finally, households headed by someone who was born outside the community are about 15 percentage points less likely to report the right to transfer their land than are other households in Côte d'Ivoire. This highlights the importance of one's status in a community in determining property rights (Goldstein and Udry 2008). The data reveal no such correlation in Ghana. One potential reason is that such migration is more common in Ghana, as reported in Table 4 . $^{4}$

I undertook fieldwork in October 2008 and January 2009 to investigate how rural households interpret these transfer rights questions. In particular, I interviewed members of 27 agricultural households in rural communities in southern Ghana, asking them whether they had the right to sell their land and then exploring the reasons for their answers to provide insight into how the GLSS households likely interpreted the transfer rights questions. Most household heads reported that they did not have the right to sell their land. The main reason given was that the land belonged to their extended family. Some household heads also reported that they would have to get permission from the chief to sell the land and would have to pay the chief one-third of the sale price. Everyone I interviewed seemed to understand what I was asking. The concept of land sales is evidently well understood in these communities, but families and chiefs put restrictions on land sales.

\footnotetext{
${ }^{4}$ Note that the Household Head Born Elsewhere measure of migration reported in Tables 3 and 4 includes nationals who were born elsewhere in the country, not just nonnationals who immigrated to the country from abroad. Côte d'Ivoire has experienced significantly more immigration: 10 percent of the sample from the Côte d'Ivoire Living Standards Survey (CILSS) has a nonnational household head, compared with only 2 percent of the sample from the Ghana Living Standards Survey (GLSS).
} 
Table 3

Household-Level Correlates of Land Transfer Rights

\begin{tabular}{|c|c|c|c|c|}
\hline & \multicolumn{2}{|c|}{ Ghana } & \multicolumn{2}{|c|}{ Côte d'Ivoire } \\
\hline & $\begin{array}{l}\text { Right to Rent } \\
\text { out Land } \\
\text { (1) }\end{array}$ & $\begin{array}{l}\text { Right to } \\
\text { Sell Land } \\
\text { (2) }\end{array}$ & $\begin{array}{l}\text { Right to Rent } \\
\text { out Land } \\
\text { (3) }\end{array}$ & $\begin{array}{l}\text { Right to } \\
\text { Sell Land } \\
\quad(4)\end{array}$ \\
\hline \multicolumn{5}{|l|}{$\log$ (Amount of Land Owned by the } \\
\hline Household) & $\begin{array}{l}.092^{\star *} \\
(.017)\end{array}$ & $\begin{array}{l}.060^{\star *} \\
(.014)\end{array}$ & $\begin{array}{l}.106^{\star *} \\
(.019)\end{array}$ & $\begin{array}{l}.068^{* *} \\
(.017)\end{array}$ \\
\hline $\log ($ Value of Land $)$ & $\begin{array}{l}.026^{* *} \\
(.010)\end{array}$ & $\begin{array}{l}.011 \\
(.009)\end{array}$ & $\begin{array}{l}.009 \\
(.009)\end{array}$ & $\begin{array}{c}.010 \\
(.008)\end{array}$ \\
\hline Grows Coffee or Grows Cocoa & $\begin{array}{l}.118^{\star *} \\
(.036)\end{array}$ & $\begin{array}{l}.090^{\star *} \\
(.030)\end{array}$ & $\begin{array}{l}.133^{\star *} \\
(.039)\end{array}$ & $\begin{array}{c}.018 \\
(.033)\end{array}$ \\
\hline Household Head Male & $\begin{array}{r}-.018 \\
(.028)\end{array}$ & $\begin{array}{r}-.014 \\
(.024)\end{array}$ & $\begin{array}{r}-.005 \\
(.048)\end{array}$ & $\begin{array}{c}-.038 \\
(.036)\end{array}$ \\
\hline Age of Household Head & $\begin{array}{l}.004^{\star *} \\
(.001)\end{array}$ & $\begin{array}{l}.005^{\star *} \\
(.001)\end{array}$ & $\begin{array}{l}.002^{\star} \\
(.001)\end{array}$ & $\begin{array}{r}-.0004 \\
(.0007)\end{array}$ \\
\hline Household head Attended School & $\begin{array}{l}.075^{\star *} \\
(.027)\end{array}$ & $\begin{array}{r}-.009 \\
(.024)\end{array}$ & $\begin{array}{l}.044 \\
(.030)\end{array}$ & $\begin{array}{c}.020 \\
(.022)\end{array}$ \\
\hline Household Head Born Elsewhere & $\begin{array}{r}-.040 \\
(.025)\end{array}$ & $\begin{array}{l}.008 \\
(.021)\end{array}$ & $\begin{array}{c}-.140^{\star *} \\
(.032)\end{array}$ & $\begin{array}{c}-.150^{* *} \\
(.039)\end{array}$ \\
\hline Household Size & $\begin{array}{r}-.009^{*} \\
(.004)\end{array}$ & $\begin{array}{l}.005 \\
(.004)\end{array}$ & $\begin{array}{l}.001 \\
(.003)\end{array}$ & $\begin{array}{r}-.001 \\
(.002)\end{array}$ \\
\hline $\log ($ Household Expenditure per Capita) & $\begin{array}{r}-.017 \\
(.020)\end{array}$ & $\begin{array}{l}.032^{+} \\
(.019)\end{array}$ & $\begin{array}{r}-.017 \\
(.022)\end{array}$ & $\begin{array}{c}.003 \\
(.021)\end{array}$ \\
\hline$N$ & 1,828 & 1,830 & 2,103 & 2,103 \\
\hline$R^{2}$ & .38 & .36 & .33 & .55 \\
\hline
\end{tabular}

Note. All regressions include enumeration area (EA) fixed effects. The sample is all households in the Ghana Living Standards Survey rounds 1 and 2 (1987-89) and the Côte d'Ivoire Living Standards Survey (1985-88) who owned agricultural land. Regressions are weighted with sample weights provided by the Living Standards Measurement Study Office for Côte d'Ivoire. Standard errors, in parentheses, are clustered at the EA level.

+ Significant at the .10 level.

* Significant at the .05 level.

** Significant at the .01 level.

\subsection{Empirical Framework}

The discussion above makes clear that the Ghanaian and Ivorian states diverged in their de jure law on property in land. A naive way to estimate the effects of that divergence would be to compare mean outcomes in the two countries. Table 4 presents the country means, which under a naive interpretation are consistent with the view that differences in de jure law had a large impact on the de facto institutional environment: 67 percent and 44 percent of Ivorian households report the right to rent out and to sell their land, respectively, compared with only 38 percent and 21 percent of Ghanaian households.

However, the problem with this approach is that the two countries differ in ways unrelated to state policy and law that might affect property rights institutions. For example, the ethnic groups that predominate in western Côte d'Ivoire are quite different from those in eastern Ghana. A comparison of means at the 
Table 4

Comparison of Survey Responses for Ghana and Côte d'Ivoire

\begin{tabular}{|c|c|c|c|}
\hline & Ghana & Côte d'Ivoire & Difference \\
\hline Right to Rent out Land & .381 & .669 & $\begin{array}{c}-.288^{* *} \\
(.025)\end{array}$ \\
\hline Right to Sell Land & .211 & .443 & $\begin{array}{c}-.232^{* *} \\
(.034)\end{array}$ \\
\hline Rented out Land in Last 12 Months & .062 & .150 & $\begin{array}{c}-.088^{* *} \\
(.017)\end{array}$ \\
\hline Sold Land in Last 12 Months & .008 & .004 & $\begin{array}{l}.004 \\
(.003)\end{array}$ \\
\hline Fraction of Land Fallow & .288 & .313 & $\begin{array}{c}-.024 \\
(.018)\end{array}$ \\
\hline Grows Cocoa & .274 & .427 & $\begin{array}{c}-.153^{* *} \\
(.033)\end{array}$ \\
\hline Grows Coffee & .010 & .445 & $\begin{array}{c}-.435^{* *} \\
(.027)\end{array}$ \\
\hline Grows Cocoa or Grows Coffee & .276 & .583 & $\begin{array}{c}-.308^{* *} \\
(.045)\end{array}$ \\
\hline Household Head Male & .727 & .936 & $\begin{array}{c}-.209^{* *} \\
(.016)\end{array}$ \\
\hline Age of Household Head & 45.3 & 50.4 & $\begin{array}{c}-5.1^{\star *} \\
(.6)\end{array}$ \\
\hline Household Head Attended School & .505 & .198 & $\begin{array}{l}.307^{\star *} \\
(.034)\end{array}$ \\
\hline Household Head Literate & .382 & .175 & $\begin{array}{l}.207^{\star *} \\
(.018)\end{array}$ \\
\hline Household Head Numerate & .435 & .207 & $\begin{array}{l}.228^{* *} \\
(.020)\end{array}$ \\
\hline Household Head Born Elsewhere & .455 & .270 & $\begin{array}{l}.185^{\star *} \\
(.031)\end{array}$ \\
\hline Distance to Border (kilometers) & 199.8 & 262.4 & $\begin{array}{c}-62.61^{\star *} \\
(13.07)\end{array}$ \\
\hline
\end{tabular}

Note. The sample is all households in the Ghana Living Standards Survey rounds 1 and 2 (1987-89) and the Côte d'Ivoire Living Standards Survey (1985-88) that owned agricultural land. Population means for Côte d'Ivoire are estimated with survey sample weights provided by the Living Standards Measurement Study Office. Standard errors, in parentheses, are corrected for heteroskedasticity, account for the stratified sampling design, and are clustered at the enumeration area level.

$* \star$ Significant at the .01 level.

country level would confound differences due to state policy with these differences that are not due to state policy.

\subsubsection{Regression Discontinuity}

Instead, I exploit the discontinuous change in state that occurs at the border between the countries to estimate the cumulative effect of state policy and de jure law at the border. Formally, I estimate the size of the discontinuous jump in the conditional expectation of measures of property rights institutions at the border. The intuition behind this approach is straightforward. While areas of Ghana and Côte d'Ivoire located far from the border are quite different, as one approaches the border between the two countries, the geography and precolonial ethnic groups 
and institutions on either side converge. Any differences now between the households just on either side of the border are due to differences in the de jure law and state policy in the two countries, not to preexisting differences.

This sharp regression discontinuity (SRD) approach can be formalized in a potential outcomes framework as follows. ${ }^{5}$ Let $Y_{i}(0)$ and $Y_{i}(1)$ denote potential outcomes for household $i$ for some outcome variable $Y$, such as whether the household has the right to sell its land. The term $Y_{i}(0)$ is the outcome if household $i$ is treated by the law and state policies of Côte d'Ivoire, and $Y_{i}(1)$ is its outcome if it is treated by the law and state polices of Ghana. The unit-level causal effect of state policy is defined as $Y_{i}(1)-Y_{i}(0)$. The fundamental problem, of course, is that for any household $i$ we observe only one potential outcome, namely, $Y_{i}(0)$ for households in Côte d'Ivoire and $Y_{i}(1)$ for households in Ghana. The regression discontinuity $(\mathrm{RD})$ design solves this problem by imputing the missing potential outcomes with data from households just on either side of the border, which allows us to estimate an average causal effect for the subpopulation of households at the border.

To see this, let $S_{i} \in\{0,1\}$ denote the state that household $i$ resides in, with $S_{i}=1$ (0) denoting Ghana (Côte d'Ivoire). Furthermore, let $D_{i}$ be the distance from household $i$ to the border between Ghana and Côte d'Ivoire, with positive (negative) values indicating households that live east (west) of the border. The term $S_{i}$ is a deterministic function of $D_{i}$ :

$$
S_{i}=1\left(D_{i} \geq 0\right) \text {. }
$$

This discontinuity in the assignment of households to states allows us to consistently estimate the average causal effect of the states' differences in policy for households that live at the border, defined as $\tau_{\mathrm{SRD}}=E\left[Y_{i}(1)-Y_{i}(0) \mid D_{i}=\right.$ $0]$. To estimate $\tau_{\mathrm{SRD}}$, we must assume that $E[Y(0) \mid D=d]$ and $E[Y(1) \mid D=$ $d$ ] are both continuous in $d$ at $d=0$. With this smoothness assumption, we have that $\tau_{\mathrm{SRD}}=\lim _{d \downarrow 0} E[Y \mid D=d]-\lim _{d \uparrow 0} E[Y \mid D=d]$. These two limits can be estimated using standard regression function estimation techniques.

The fact that the border was drawn arbitrarily and did not follow precolonial divisions between ethnic groups is key to the validity of this approach. This ensures that determinants of property rights institutions unrelated to state policy vary continuously at the border. The border between the Gold Coast (as colonial Ghana was called) and Côte d'Ivoire was determined through a series of AngloFrench agreements between 1893 and 1905 (Brownlie 1979). The border was demarcated by concrete beacons, with about half of the boundary based on a river or stream and half based on straight lines between landmarks. The resulting border did not follow ethnic lines and instead split a series of ethnic groups in two, including the Assini, Anyi, Brong, Dagari, and Ligbi Degha (Barbour 1962, pp. 306-7, 312-13).

\footnotetext{
${ }^{5}$ See Imbens and Lemieux (2008) for a detailed treatment of regression discontinuity designs, on which the discussion that follows draws.
} 
Another important assumption underpinning this strategy is that the CILSS and GLSS are comparable surveys, so that the survey design does not induce a jump in measures of property rights at the border. The CILSS and GLSS were both coordinated by the LSMS Office at the World Bank. The CILSS was started first, and the GLSS questionnaire was based on the CILSS questionnaire. Some differences were introduced in the GLSS questionnaire, but they are minor and seem unlikely to cause significant differences in survey responses. Table A1 details the differences between the survey questions used in the analysis.

This RD design has several important limitations. First, it can only be used to investigate the effect of the complete bundle of laws and state-level policies that differ between Ghana and Côte d'Ivoire. It cannot isolate the effect of any individual component of that bundle. Thus, the estimates reported below should not be interpreted as estimates of the effect of just the differences in de jure property law in the two states but rather as the combined effect of those differences as well as other differences in state policy, such as agricultural policy and education policy.

Second, an $\mathrm{RD}$ approach estimates only the local average treatment effect at the border, not the average treatment effect across the full sample. The border area is rural and relatively remote from either country's capital. This research design cannot reveal the effect of law and state policy on property rights in urban areas or in areas close to the national capitals.

\subsubsection{Estimation}

To estimate the jump in the conditional expectation of each outcome variable at the border, I estimate equations of the form

$$
Y_{i}=\beta_{0}+\beta_{1} S_{i}+f\left(D_{i}\right)+S_{i} \times g\left(D_{i}\right)+\varepsilon_{i},
$$

where $f\left(D_{i}\right)$ and $g\left(D_{i}\right)$ are polynomials in distance to the border. I use two basic specifications: a global fourth-order polynomial regression using all of the data and a local linear regression using only data near the border. To determine the bandwidth for the local linear regression, I calculate the Fan and Gijbels (1996) rule-of-thumb bandwidth, as suggested by Lee and Lemieux (2010). ${ }^{6}$ I report local linear regression estimates using these rule-of-thumb bandwidths, and to check robustness I also use twice and half those bandwidths for each outcome variable. I perform the analysis at the household level, with standard errors clustered at the EA level. All results are robust to collapsing the data to the EA level and performing the same analysis on EA-level means with spatial standard errors calculated using the estimator in Conley (1999) (not reported for brevity).

As shown in Figure 1, Ghana extends farther north than does Côte d'Ivoire.

\footnotetext{
${ }^{6}$ For either side of the border, the rule-of-thumb bandwidth is equal to $[2.702 \times$ MSE $\times$ Range/ $\left.\sum \tilde{m}^{\prime \prime}\left(\text { dist }_{j}\right)^{2}\right]^{1 / 5}$, where MSE is the mean squared error from a regression of the dependent variable on a fourth-order polynomial of distance to the border, Range is the range of distance to the border in that sample, and $\tilde{m}^{\prime \prime}\left(\right.$ dist $\left._{j}\right)$ is the estimated second derivative of that regression function, which is summed over the full sample.
} 


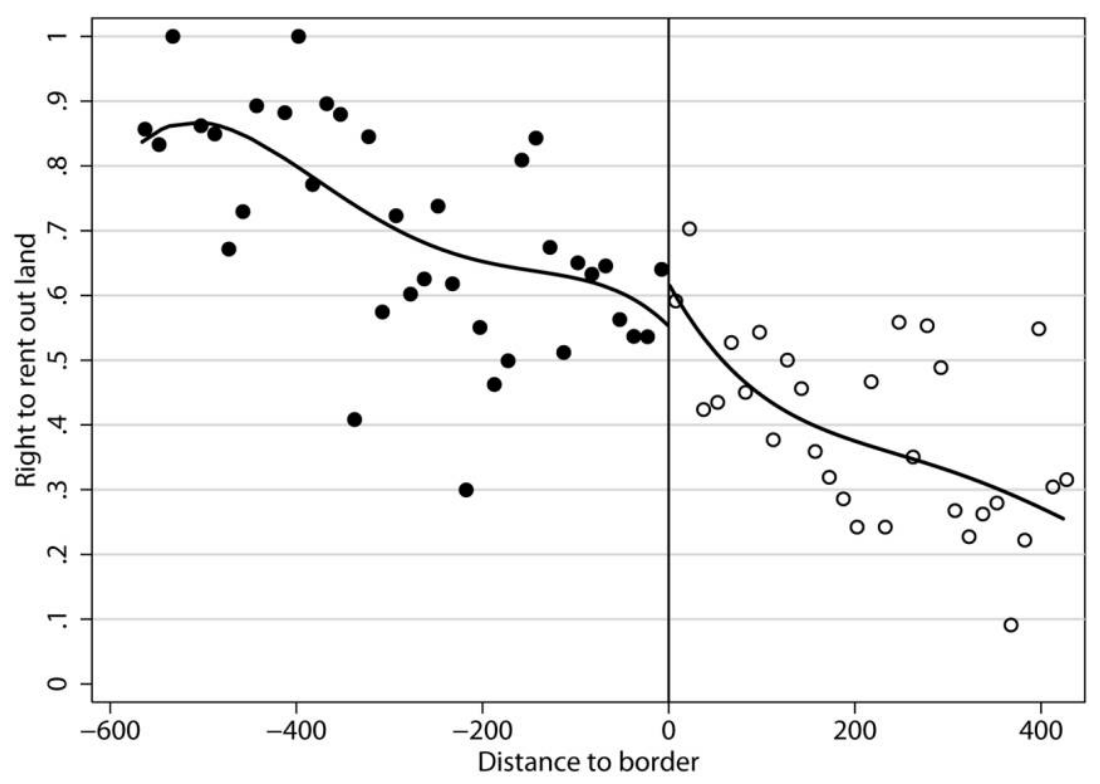

Figure 2. Right to rent out land, by distance to the border

Because there are no comparison units in Côte d'Ivoire for the EAs in Ghana that are north of the northernmost point on their border, I discard them. Note as well that virtually the full sample of EAs near the border are in the southern half of the countries, with only a single EA in the drier northern half of the border region. The EAs were selected from a census list with a probability proportional to the population, so this is a consequence of very low population density in the northern border region.

\subsection{Results}

\subsubsection{Property Rights Institutions}

I turn now to $\mathrm{RD}$ estimates that measure the change in property rights institutions at the border. Figure 2 shows the regression discontinuity plot for the right to rent out land. ${ }^{7}$ The scatterplot of local averages suggests no discontinuity in land rights at the border and shows a striking linear relationship between longitude and the right to rent out land, decreasing from west to east. The fourth-order polynomial fit on either side of the border shows very little gap in the regression functions at the border.

The point estimates are provided in Table 5. Confirming the visual evidence,

${ }^{7}$ In Figures 2-10, the local averages in 15-kilometer bins are plotted. The fitted lines are from the fourth-order polynomial regressions. 
Table 5

Regression Discontinuity Estimates of the Effect of the State on Land Rights and Use

\begin{tabular}{|c|c|c|c|c|}
\hline & \multirow{2}{*}{$\begin{array}{c}\text { Global } \\
\text { Fourth-Order } \\
\text { Polynomial } \\
(1)\end{array}$} & \multicolumn{3}{|c|}{ Local Linear, by Bandwidth } \\
\hline & & $\begin{array}{l}\text { Rule of Thumb } \\
\text { (2) }\end{array}$ & $\begin{array}{l}\text { Twice } \\
\text { (3) }\end{array}$ & $\begin{array}{l}\text { Half } \\
(4)\end{array}$ \\
\hline \multicolumn{5}{|l|}{ Measures of property rights institutions: } \\
\hline Right to Rent out Land: & .065 & .010 & -.055 & .058 \\
\hline SE & .116 & .083 & .059 & .113 \\
\hline Bandwidths (left, right) & $\infty, \infty$ & 175,157 & 350,314 & 87,78 \\
\hline$N$ & 3,964 & 1,582 & 3,190 & 801 \\
\hline Right to Sell Land: & .172 & .174 & $.149^{+}$ & .086 \\
\hline SE & .131 & .122 & .082 & .141 \\
\hline Bandwidths (left, right) & $\infty, \infty$ & 95,102 & 189,204 & 47,51 \\
\hline$N$ & 3,866 & 982 & 1,986 & 396 \\
\hline \multicolumn{5}{|l|}{ Measures of land use: } \\
\hline Rented out Land in Last 12 Months: & -.056 & -.040 & $-.149^{*}$ & $-.209^{\star}$ \\
\hline $\mathrm{SE}$ & .100 & .098 & .060 & .095 \\
\hline Bandwidths (left, right) & $\infty, \infty$ & 104,99 & 208, 199 & 52,50 \\
\hline$N$ & 3,962 & 979 & 1,998 & 431 \\
\hline Fraction of Land Fallow: & .074 & $.138^{*}$ & $.111^{*}$ & -.002 \\
\hline SE & .076 & .065 & .046 & .086 \\
\hline Bandwidths (left, right) & $\infty, \infty$ & 161,73 & 125,116 & 80,36 \\
\hline$N$ & 3,967 & 1,009 & 2,038 & 560 \\
\hline
\end{tabular}

Note. Each cell represents a feature of a regression. The coefficient reported is the estimated discontinuous jump at the border from Côte d'Ivoire to Ghana. The sample is all households in the Ghana Living Standards Survey rounds 1 and 2 (1987-89) and the Côte d'Ivoire Living Standards Survey (1985-88) that owned agricultural land and lived south of the northernmost point on the Ghana-Côte d'Ivoire border. Regressions are weighted with sample weights provided by the Living Standards Measurement Study Office for Côte d'Ivoire. Standard errors are clustered at the enumeration area level. The results from the global fourthorder polynomial were estimated separately on each side of the border. The results using rule-of-thumb bandwidths follow Fan and Gijbels (1996).

+ Significant at the .05 level.

the point estimates are close to zero, and none are statistically significant. Figure 3 and Table 5 show the results for the right to sell land. The basic pattern is the same: despite substantial differences in country means, the regression functions meet at the border, and there is little evidence of a discontinuity in the right to sell land. The estimates using both the global polynomial regression and the local linear regression using the rule-of-thumb bandwidth are not significantly different from zero. The estimate using twice the rule-of-thumb bandwidth is a marginally significant (at the 10 percent level) 15 percentage points, but with a sign the opposite to that predicted by the existing secondary literature.

One possible concern is that a change in the share of nonnationals in the two countries might be masking an underlying shift in the property rights of nationals. Ten percent of sample households in Côte d'Ivoire are headed by a nonnational, compared with only 2 percent of households in Ghana. Since nonnationals generally have weaker property rights than nationals, the higher fraction of nonnationals in Côte d'Ivoire can generally be expected to decrease reported 


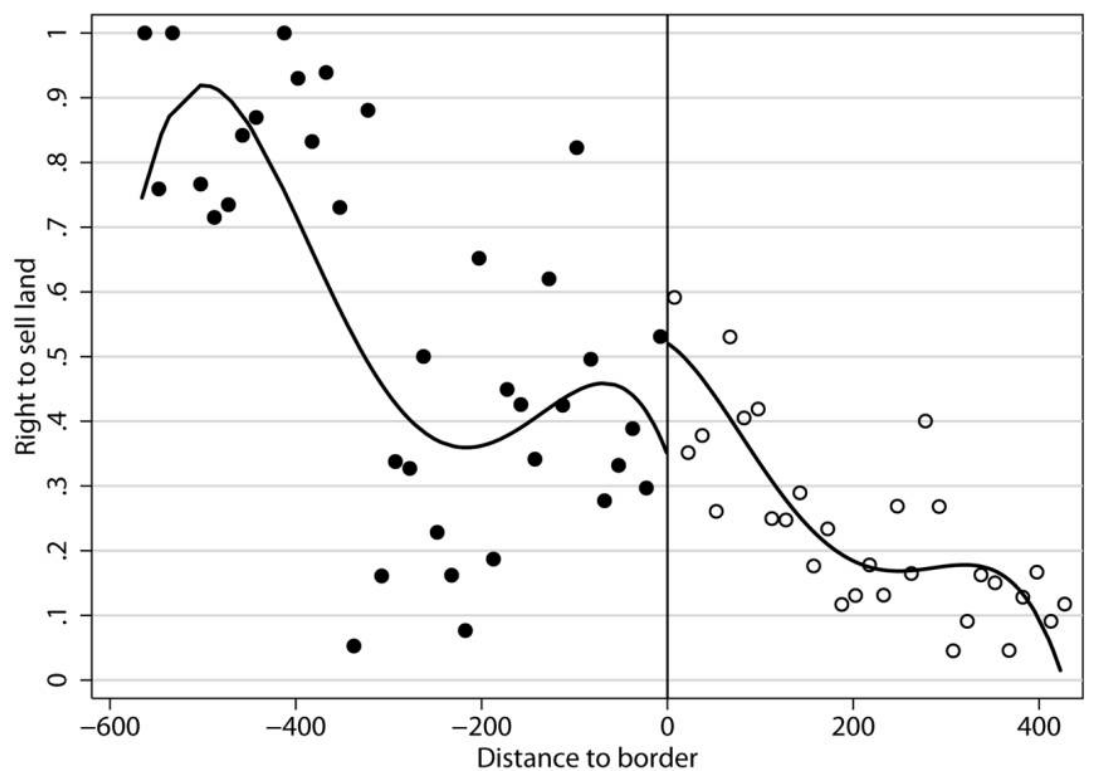

Figure 3. Right to sell land, by distance to the border

property rights. To test this, I exclude nonnationals and estimate the discontinuity in property rights institutions among nationals. The results are qualitatively unchanged (not reported for brevity).

The data thus show that, despite being subject to very different de jure legal regimes and state policies, households just on either side of the border are subject to similar de facto norms governing property rights in land. This suggests that states play a limited role in property rights institutions in the area near the border and instead nonlegal sources of norms are the crucial determinants of de facto institutions.

\subsubsection{Land Use}

In addition to examining whether state-level policies have had an effect on property rights institutions in this context, I investigate whether these state-level policies have had an effect on land use outcomes. Consider first actual land rental market activity. The prevalence of land rentals is not solely a function of property rights institutions. Rather, it is a measure of behavior under a given set of institutions. But it is natural to expect the supposed liberalization of land transfers in Côte d'Ivoire to have resulted in more land transfers. In fact, Figure 4 again shows the same basic pattern in the prevalence of land rentals- the estimated regression functions come together at the border. The point estimates are presented in Table 5. The preferred estimates in columns 1 and 2 are not 


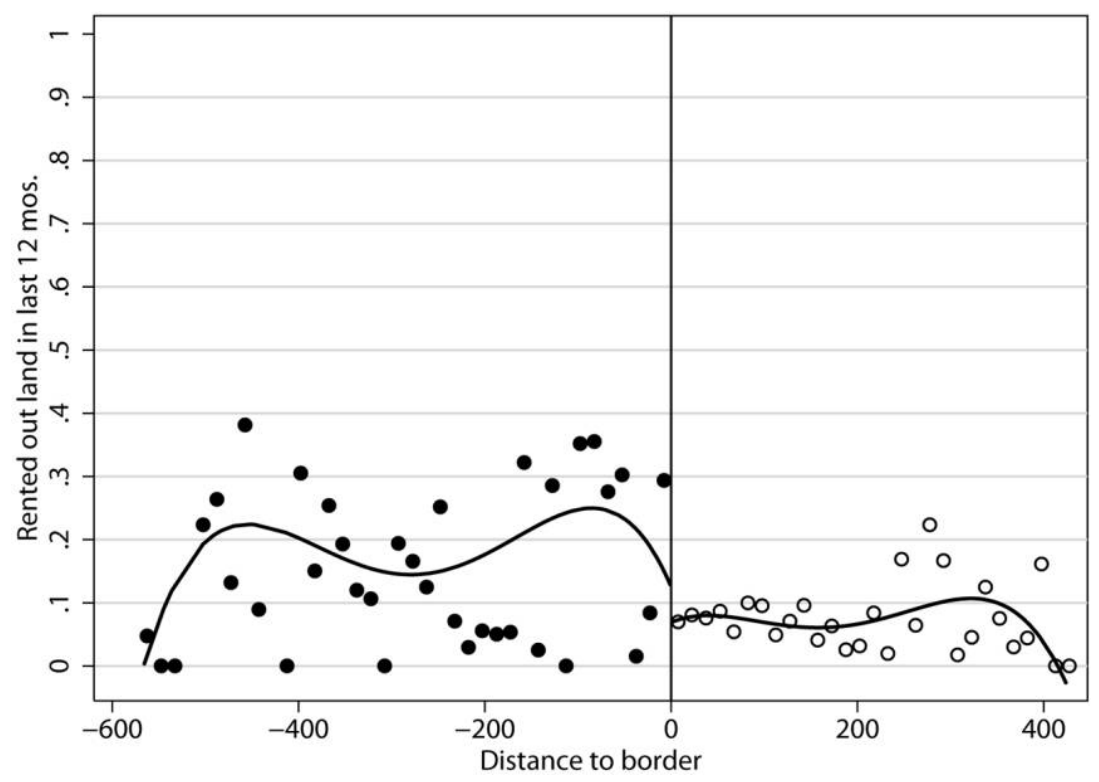

Figure 4. Rented out land, by distance to the border

significantly different from zero. But the estimates using twice and half the ruleof-thumb bandwidths are a statistically significant -15 and -21 percentage points, respectively, and hence these results are not robust. On the whole, these results provide little evidence against the null hypothesis that state-level policies have had little effect on rental market institutions.

Another important land use variable is the fraction of land available that is currently fallow. Fallowing is an important land investment, and Goldstein and Udry (2008) show that households in Ghana with weaker property rights fallow their land for shorter durations. However, there are factors other than property rights institutions that affect fallowing decisions, such as crop choices, education, and the cost of fertilizer. We can use the same RD approach to investigate whether state-level policies have had an effect on household fallowing behavior. Figure 5 and Table 5 show the discontinuity in the fraction of land fallowed by the household. The data provide some evidence of an effect. While the scatterplot does not show an obvious discontinuity, and the polynomial-based estimate is insignificant, the estimate using a local linear regression is a statistically significant 13.8-percentage-point increase in the fraction of land fallowed in Ghana (although column 4 shows that this result is not robust to a smaller bandwidth). One possibility is that this reflects differences in tenure security, which is a dimension of property rights institutions for which the data set lacks a good measure. Hence, these results provide a minor qualification to my finding that 


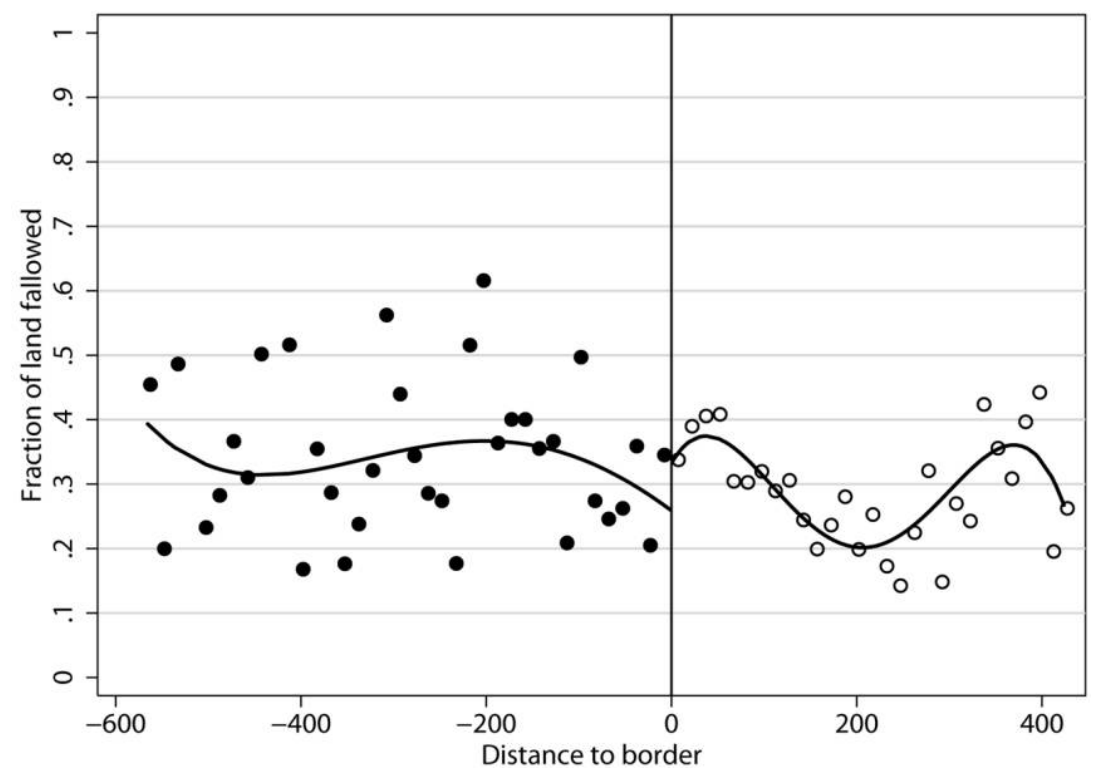

Figure 5. Fraction of land fallowed, by distance to the border

transfer rights measures are continuous at the border. However, this qualification is minor because of the lack of robustness of the result and because fallowing behavior may be affected by state policies that do not affect institutions, such as the educational and agricultural policies discussed next.

\subsubsection{Other Economic Outcomes}

One interpretation of the lack of a discontinuity in property rights institutions at the border is that the border and the state simply do not matter. I turn now to other economic outcomes that may be affected by state policy to investigate whether states are completely ineffectual in this context.

States likely have an impact on human capital accumulation through education policy, and Ghana and Côte d'Ivoire's education policies diverged beginning in the colonial period. The British placed more emphasis on primary education in their African colonies, including in the indigenous languages, whereas the French adopted an assimilationist approach, focusing on secondary education to create "French citizens" out of a narrower segment of the population. In consequence, primary enrollment rates were much higher in British than in French colonies (Benavot and Riddle 1988). My RD approach confirms that state policies had a big impact on schooling outcomes in Ghana and Côte d'Ivoire. Figure 6 shows that at the border there is a dramatic discontinuity in whether the household head ever attended school. The point estimates are presented in Table 6. The 


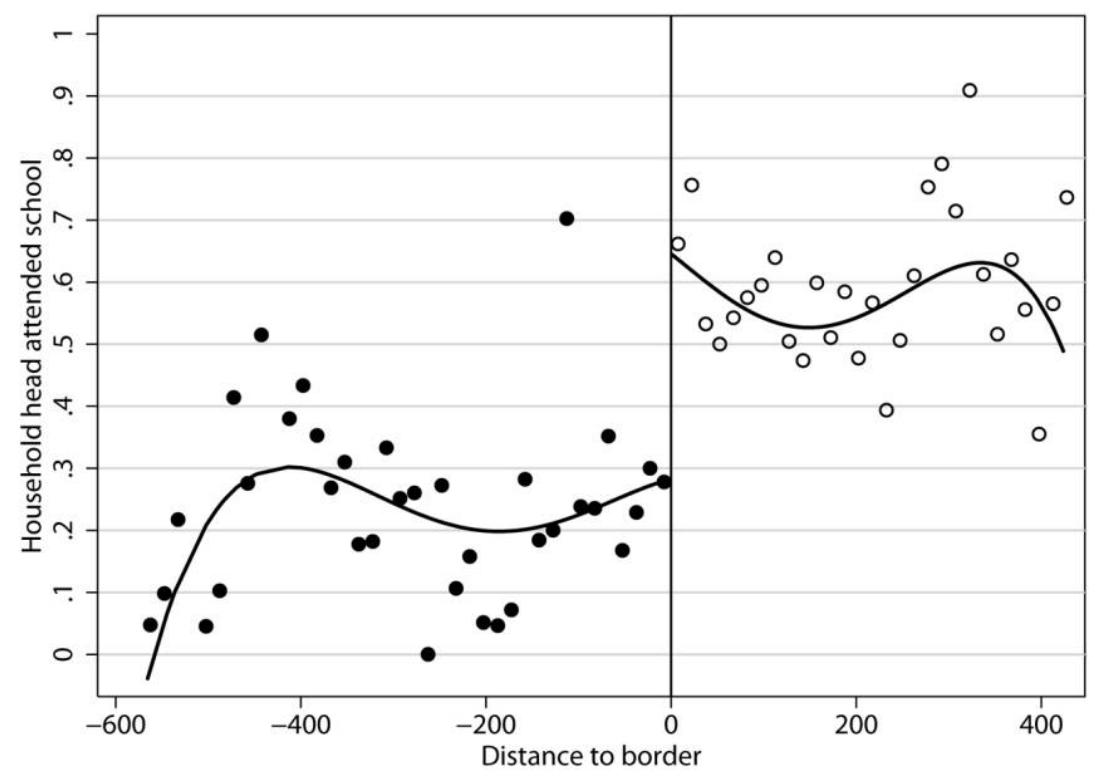

Figure 6. Household head attended school, by distance to the border

fourth-order polynomial point estimate indicates a 36-percentage-point effect of state policy on school attendance at the border.

Moreover, these differences in schooling have real effects on human capital. Figures 7 and 8 and Table 6 show RD estimates of the effect of the state on the literacy and numeracy of the household head. The fourth-order polynomial estimate indicates a 12-percentage-point increase in literacy, but it is not statistically significant. The local linear regression-based estimate in column 2 shows a statistically significant 16-percentage-point jump. The point estimates for numeracy are all statistically significant, with the global polynomial estimate at 22 percentage points.

Another major activity of African states is regulation of export crop markets (Bates 1984). Both states established marketing boards to regulate the price farmers receive for export crops, ostensibly to insure farmers against fluctuations in the world price but in practice imposing a substantial tax on farmers' production. While cocoa is a major export crop in both countries, coffee is grown mainly in Côte d'Ivoire, with little Ghanaian production. The French have historically purchased most of Côte d'Ivoire's coffee output, paying a 50 percent premium over the world price (Due 1969), and have put restrictions on coffee imports from outside of French West Africa (Zolberg 1969, pp. 163-70). Figure 9 and Table 6 show the RD results for whether the household grows coffee and confirm that the state had a large impact on production. At the border, where 
Table 6

Regression Discontinuity Estimates of the Effect of the State on Other Outcomes

\begin{tabular}{|c|c|c|c|c|}
\hline & \multirow{2}{*}{$\begin{array}{c}\text { Global } \\
\text { Fourth-Order } \\
\text { Polynomial } \\
\text { (1) }\end{array}$} & \multicolumn{3}{|c|}{ Local Linear, by Bandwidth } \\
\hline & & $\begin{array}{l}\text { Rule of Thumb } \\
\text { (2) }\end{array}$ & $\begin{array}{l}\text { Twice } \\
(3)\end{array}$ & $\begin{array}{c}\text { Half } \\
(4)\end{array}$ \\
\hline Household Head Attended School: & $.363^{\star *}$ & $.325^{\star \star}$ & $.339^{* *}$ & $.405^{\star *}$ \\
\hline SE & .100 & .085 & .052 & .120 \\
\hline Bandwidths (left, right) & $\infty, \infty$ & 125,116 & 249,232 & 62,58 \\
\hline$N$ & 3,967 & 1,109 & 2,505 & 478 \\
\hline Household Head Literate: & .124 & $.164^{\star}$ & $.160^{* *}$ & .185 \\
\hline SE & .093 & .076 & .050 & .117 \\
\hline Bandwidths (left, right) & $\infty, \infty$ & 134,94 & 267,187 & 67,47 \\
\hline$N$ & 3,967 & 1,013 & 2,219 & 447 \\
\hline Household Head Numerate: & $.224^{*}$ & $.261^{\star *}$ & $.188^{\star *}$ & $.248^{+}$ \\
\hline SE & .098 & .098 & .060 & .095 \\
\hline Bandwidths (left, right) & $\infty, \infty$ & 111,99 & 223,199 & 56,50 \\
\hline$N$ & 3,967 & 997 & 2,040 & 431 \\
\hline Grows Coffee: & $-.577^{\star \star}$ & $-.528^{\star *}$ & $-.533^{\star *}$ & $-.506^{\star *}$ \\
\hline SE & .086 & .077 & .061 & .095 \\
\hline Bandwidths (left, right) & $\infty, \infty$ & 123,98 & 246,196 & 62,49 \\
\hline$N$ & 3,967 & 1,012 & 2,182 & 447 \\
\hline
\end{tabular}

Note. Each cell represents a feature of a regression. The coefficient reported is the estimated discontinuous jump at the border from Côte d'Ivoire to Ghana. The sample is all households in the Ghana Living Standards Survey rounds 1 and 2 (1987-89) and the Côte d'Ivoire Living Standards Survey (1985-88) that owned agricultural land and lived south of the northernmost point on the Ghana-Côte d'Ivoire border. Regressions are weighted with sample weights provided by the Living Standards Measurement Study Office for Côte d'Ivoire. Standard errors are clustered at the enumeration area level. The results from the global fourthorder polynomial were estimated separately on each side of the border. The results using local linear regressions with rule-of-thumb bandwidths follow Fan and Gijbels (1996).

${ }^{+}$Significant at the .10 level.

* Significant at the .05 level.

** Significant at the .01 level.

the geographic suitability for coffee cultivation is the same in the two countries, Côte d'Ivoire produces dramatically more coffee.

The large difference in coffee production between the states at the border raises the question of why this difference in production did not translate into a difference in property rights institutions. In Section 4, I present evidence that production of a similar crop, cocoa, resulted in an individualization of land rights in Ghana. However, in Ghana households substituted other crops-cocoa in particular-for coffee. Figure 10 shows that a similar fraction of households grow either cocoa or coffee on either side of the border. The point estimates of the discontinuity are all statistically insignificant (not reported for brevity).

\subsubsection{Discussion}

My finding that de jure law has little effect on de facto property rights institutions echoes Ellickson's (1991) findings on norms in a very different context. He found that norms about who is responsible for damage caused by trespassing cattle in Shasta County, California, are independent of the legal rule-the norm 


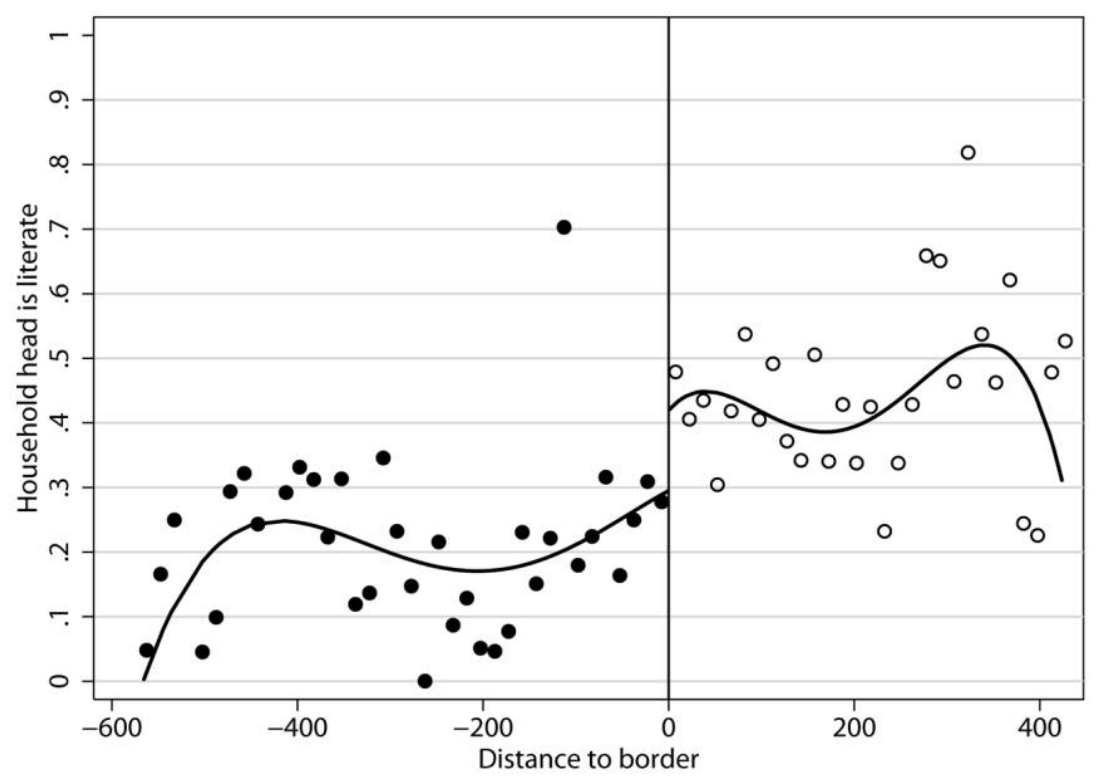

Figure 7. Household head is literate, by distance to the border

is uniformly that the owner of the cattle is responsible, even in areas where the formal legal rule makes the owner of the land responsible for fencing cattle out. Similarly, in West Africa social norms that are largely independent of formal law govern property rights.

It is important to note, though, that the data show that West African states are not completely ineffectual. In particular, it appears that states can provide public goods (for example, education) and regulate export crop production. A potential explanation for this pattern is that certain institutions, including property rights in land, are part of a set of local, nonstate institutions that are resistant to state policy. Local elites play important roles in West African customary property rights institutions, and changes to those institutions would reduce their status and wealth. Aldashev et al. (2012) present a model of the resistance of custom to formal law in which local customary elites are able to exact penalties on nonelites who appeal their judgments to formal legal institutions, which provides one mechanism for the persistence of customary law.

The interests of national elites and local elites in education policy, in contrast, are likely to be well aligned-nobody minds when the government builds a school. And while national elites' and local elites' interests in agricultural policy are in conflict, controlling export markets is relatively easy for states to do, as it does not require a substantial administrative apparatus in the hinterlands of their territory. 


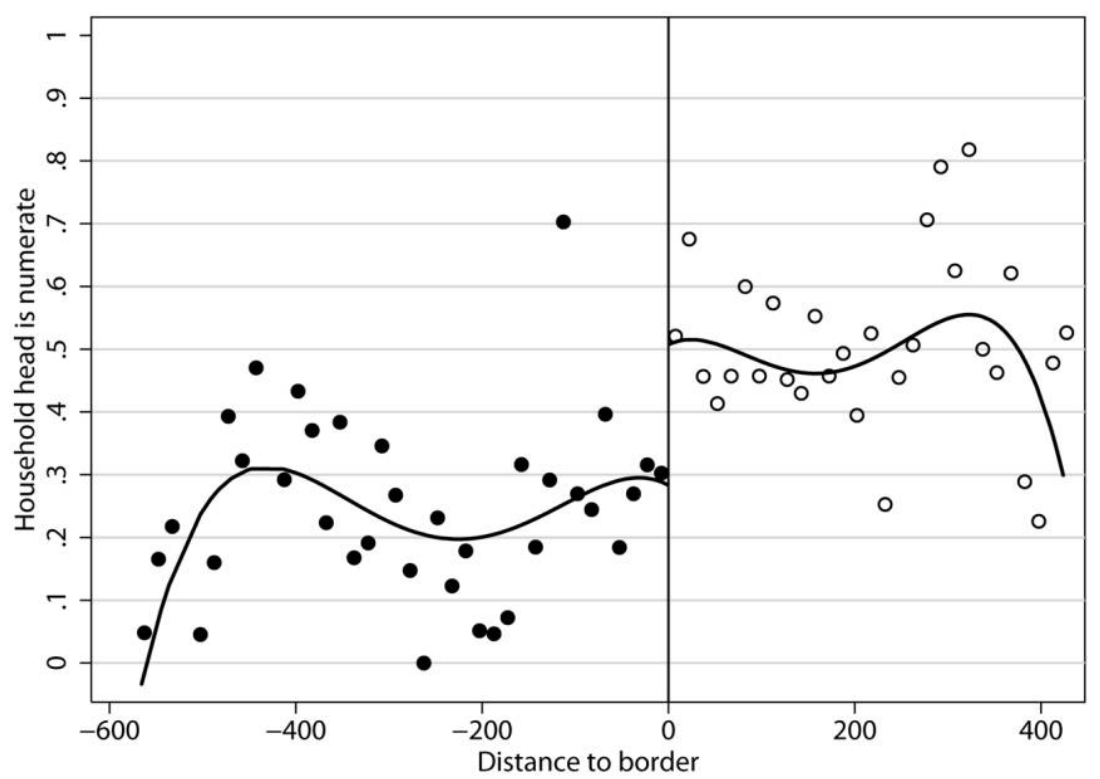

Figure 8. Household head is numerate, by distance to the border

An important limitation of my RD research design is that it identifies only the local effect of states at the border-a relatively remote rural area. While I find no effect at the border, it could be that the substantial mean differences in property rights in the two countries are nonetheless driven by channels that do not affect the border area. For example, perhaps state policies affect the kinds of industries that develop in the two states, which in turn affects property rights in areas other than the rural border area. Nonetheless, most of West Africa is rural and remote, which makes the causal effect of states at the border an estimand of substantial external validity.

\section{Explaining Within-Country Variation: The Commercialization of Agriculture}

While states evidently play little role in property rights institutions in West Africa, Figures 2 and 3 show that there is substantial variation in property rights institutions within Ghana and Côte d'Ivoire. I now use the GLSS data to investigate whether cocoa had the effect on property rights many attribute to it and hence explains part of the variation in property rights institutions within Ghana. 


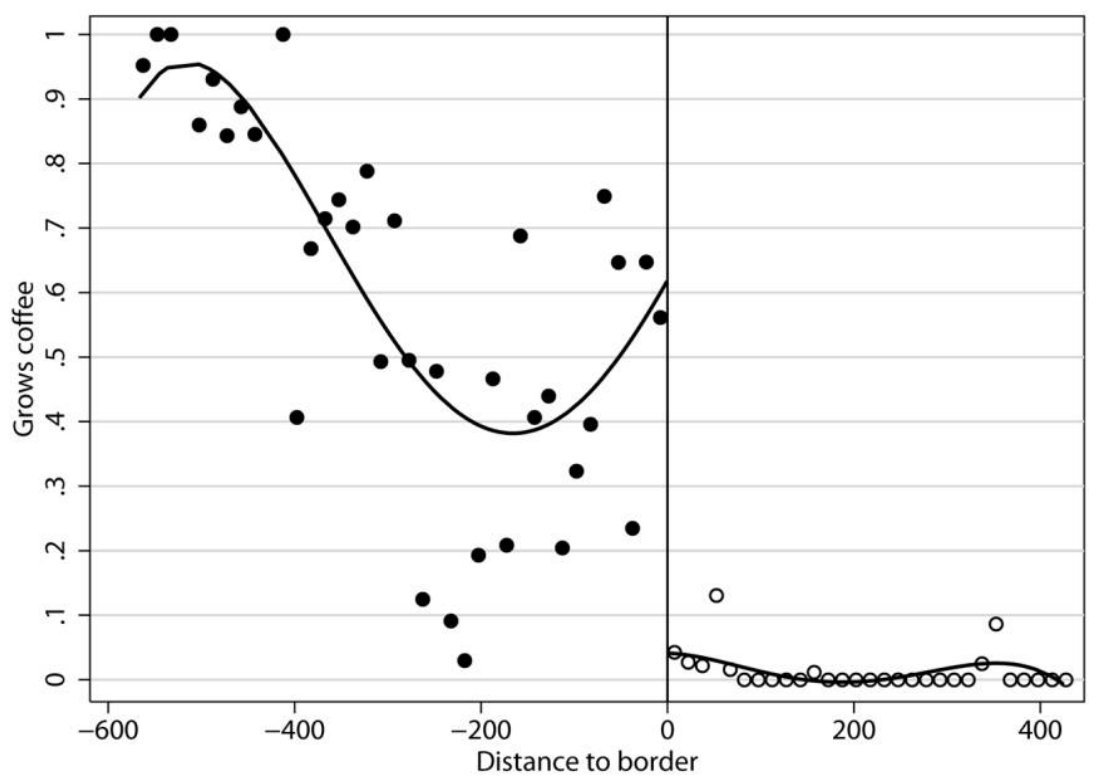

Figure 9. Household grows coffee, by distance to the border

\subsection{Empirical Framework}

As a simple structural model, consider the following equation:

$$
\text { PropRights }_{i v}=\beta_{0}+\beta_{1} \text { Cocoa }_{v}+\beta_{2} X_{v}+\varepsilon_{i v},
$$

where PropRights ${ }_{i v}$ is some measure of the strength of the property rights of household $i$ in village $v$ to its land, $\operatorname{Cocoa}_{v}$ is a measure of the extent of cocoa production in village $v$, and $\boldsymbol{X}_{v}$ is a vector of exogenous controls. A basic problem with estimating such a model is reverse causality: households with more individualized property rights may be quicker to adopt cash crop cultivation.

To deal with this identification problem, I use a geographic measure of the suitability of the land in an area for cocoa as an instrument for the adoption of cocoa. The reduced-form equation is

$$
\text { PropRights }_{i v}=\alpha_{0}+\alpha_{1} \text { CocoaSuit }_{v}+\alpha_{2} \boldsymbol{X}_{v}+\nu_{i v},
$$

where CocoaSuit $v_{v}$ is a measure of the suitability of the land around village $v$ for cultivation of cocoa. Equation (4) is not subject to any reverse causality, and estimating $\alpha_{1}$ provides a test of whether demand-side factors-that is, demand for individualized property rights institutions-have influenced the evolution of property rights. By adding an exclusion restriction assumption-that CocoaSuit ${ }_{v}$ affects property rights institutions only through its effect on cash crop produc- 


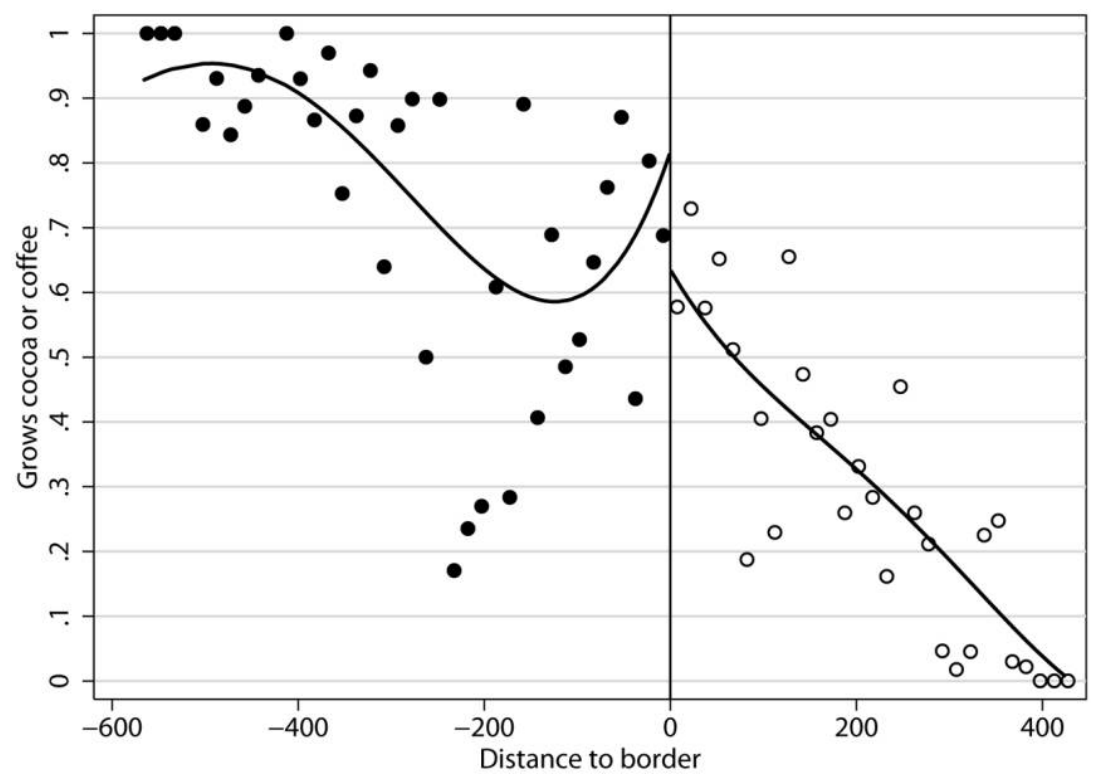

Figure 10. Household grows cocoa or coffee, by distance to the border

tion-I can further estimate the effect of cocoa production on property rights institutions, $\beta_{1}$ in equation (3), using an instrumental variables estimator.

A concern with this approach to testing the Demetzian hypothesis that institutions evolve in response to societal needs, and in particular in response to the commercialization of agriculture, is that a correlation between property rights institutions and cocoa suitability may be driven by other channels. For example, it may be that households in cocoa-growing regions are simply wealthier on average and that general development results in changes to property rights institutions. Or the results could be driven by migration. Hill (1963) recounts how the initial adopters of cocoa in Ghana migrated from their home region in search of additional land on which to cultivate cocoa after they had exhausted their own land. They bargained with chiefs in their host communities to buy land. It could be that this migration process resulted in individualization of land rights but in a non-Demsetzian way. I investigate these alternative channels below.

\subsection{Data}

I use data from the GLSS rounds 1 and 2 to measure property rights institutions and employ the same measures used in Section 3. As a measure of the suitability of land for cocoa cultivation, I use a cocoa suitability index generated by the 
Soil Research Institute (SRI) in Accra, Ghana. ${ }^{8}$ The SRI uses the Food and Agriculture Organization's agro-ecological zones methodology to produce a cocoa suitability index that takes into account precipitation, temperature, elevation, slope, and soil type to measure how suitable the land is for cocoa cultivation. The index runs from 0 to 1 .

Figure 11 provides a map with the cocoa suitability index and the EAs in the GLSS rounds 1 and 2. The darker areas of the map are more suitable for cocoa production. The boundaries are regional boundaries. Cocoa cannot be grown in the northern part of the country, so I include region dummies in all regressions so that I use only within-region variation instead of comparing the north to the south (which are very different on many dimensions).

Similarly, I control for ethnicity as a way to control for initial institutions. The GLSS does not ask for the household's precise ethnicity, but it does ask for the primary language of the household head. Responses are either one of six languages (Akan, Ewe, Ga-Adangbe, Dagbani, Hausa, and Nzema), which represent ethnic categories that capture much of the variation in initial institutions, or "other" (reported by 200 households).

\subsection{Results}

\subsubsection{First Stage}

Column 1 of Table 7 shows the result of the first-stage regression of the fraction of land in an EA planted in cocoa on the cocoa suitability index. The cocoa suitability index is strongly positively associated with cocoa production, even after controlling for region.

However, the result in column 2 shows that cocoa suitability is not correlated with whether the household head has migrated from the place he was born. This makes the migration channel less plausible as an explanation for the correlation between cocoa suitability and property rights.

Furthermore, the result in column 3 shows that there is no association between household expenditure per capita and cocoa suitability. This makes the general development channel a less plausible account of the correlation between cocoa suitability and property rights as well.

\subsubsection{Effect of Cocoa on Property Rights Institutions}

Table 8 presents estimates of the effect of cocoa cultivation on the right to rent out land. The data in column 1 are from a simple ordinary least squares (OLS) regression of a household's right to rent out its land on the fraction of land planted in cocoa in the household's EA. The correlation is strong: a 1percentage-point increase in the fraction of land planted in cocoa is associated with a .6-percentage-point increase in the prevalence of the right to rent out

\footnotetext{
${ }^{8}$ Unfortunately, I do not have data on cocoa suitability in Côte d'Ivoire and hence restrict my analysis to Ghana.
} 


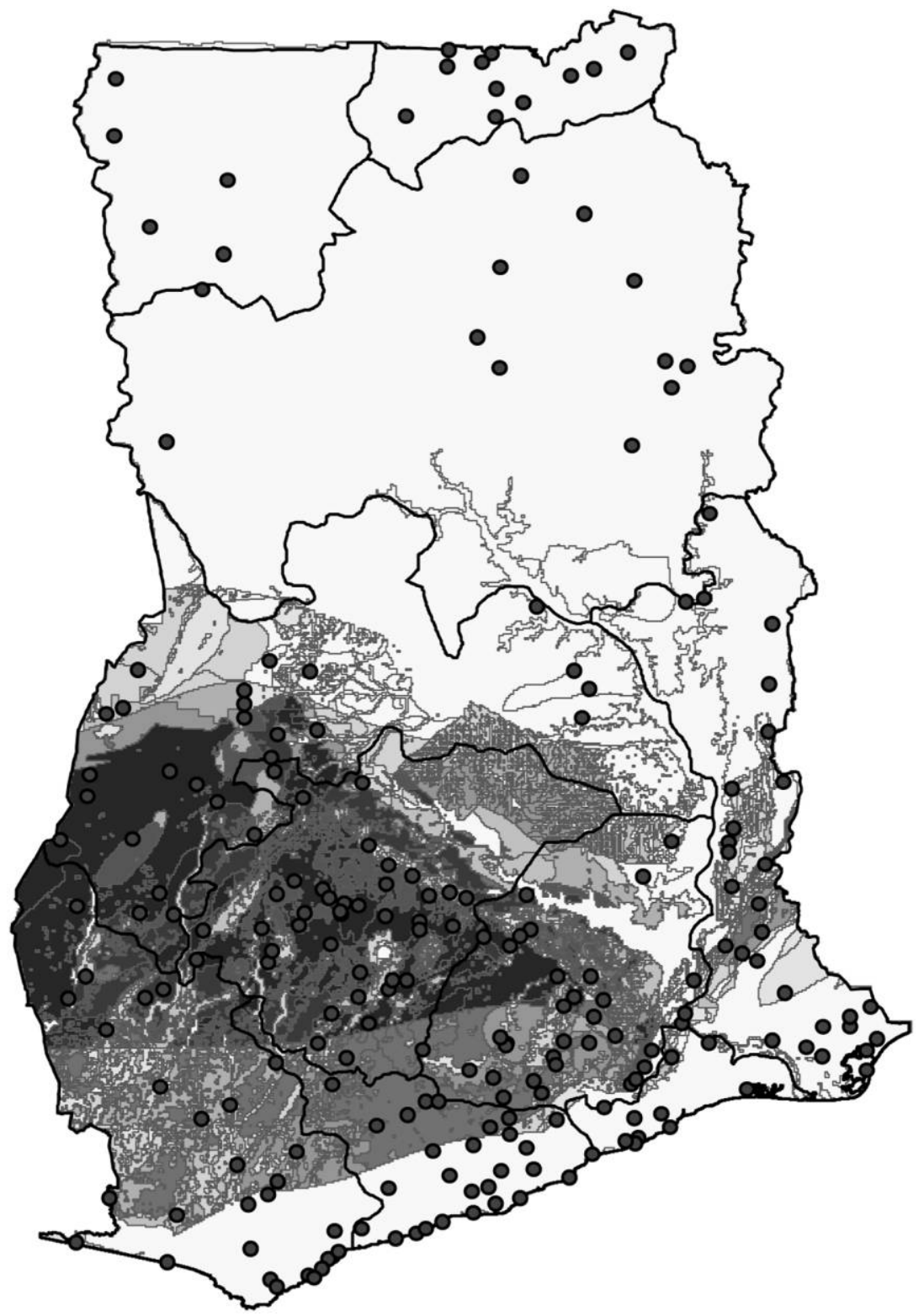

Figure 11. Cocoa suitability index and Ghana Living Standards Survey rounds 1 and 2 enumeration areas with regional boundaries. 
Table 7

First-Stage Regressions Using Cocoa Suitability

\begin{tabular}{|c|c|c|c|c|c|c|}
\hline & $\begin{array}{c}\text { FracCocoa }_{v} \\
\text { (1) }\end{array}$ & $\begin{array}{l}\text { Migrant } \\
(2)\end{array}$ & $\begin{array}{c}\log (\mathrm{HH} \operatorname{Exp}) \\
(3)\end{array}$ & $\begin{array}{c}\text { FracCocoa }_{v} \\
\text { (4) }\end{array}$ & $\begin{array}{l}\text { Migrant } \\
\text { (5) }\end{array}$ & $\begin{array}{c}\log (\mathrm{HH} \operatorname{Exp}) \\
(6)\end{array}$ \\
\hline CocoaSuit $_{v}$ & $.163^{* *}$ & $\begin{array}{c}.0773 \\
(.0786)\end{array}$ & $\begin{array}{c}.0429 \\
(.0983)\end{array}$ & $\begin{array}{l}.132^{\star *} \\
(.0299)\end{array}$ & $\begin{array}{c}.0654 \\
(.0795)\end{array}$ & $\begin{array}{l}.0893 \\
(.106)\end{array}$ \\
\hline Temperature & & & & $\begin{array}{c}.0195^{\star} \\
(.00789)\end{array}$ & $\begin{array}{l}.0725^{\star *} \\
(.0246)\end{array}$ & $\begin{array}{r}-.0941^{\star} \\
(.0406)\end{array}$ \\
\hline Temperature $^{2}$ & & & & $\begin{array}{l}.0000229 \\
(.0000142)\end{array}$ & $\begin{array}{l}.000196^{\star *} \\
(.000048)\end{array}$ & $\begin{array}{c}-.000151^{\star} \\
(.0000746)\end{array}$ \\
\hline Precipitation & & & & $\begin{array}{l}.161 \\
(.232)\end{array}$ & $\begin{array}{l}2.46^{\star \star} \\
(.770)\end{array}$ & $\begin{array}{c}-1.17 \\
(1.24)\end{array}$ \\
\hline Precipitation $^{2}$ & & & & $\begin{array}{r}-.020 \\
(.091)\end{array}$ & $\begin{array}{c}-.955^{\star \star} \\
(.276)\end{array}$ & $\begin{array}{l}.422 \\
(.438)\end{array}$ \\
\hline Constant & $\begin{array}{l}.0399 \\
(.0249)\end{array}$ & $\begin{array}{l}.354^{\star *} \\
(.0792)\end{array}$ & $\begin{array}{l}11.45^{\star *} \\
(.0910)\end{array}$ & $\begin{array}{r}-.662^{\star} \\
(.258)\end{array}$ & $\begin{array}{r}-3.18^{\star *} \\
(.937)\end{array}$ & $\begin{array}{l}14.73^{\star *} \\
(1.47)\end{array}$ \\
\hline$N$ & 2,803 & 2,800 & 2,786 & 2,803 & 2,800 & 2,786 \\
\hline$R^{2}$ & .397 & .0713 & .0656 & .4314 & .090 & .0774 \\
\hline
\end{tabular}

Note. The term CocoaSuit ${ }_{v}$ is the cocoa suitability index $\in[0,1]$. The term FracCocoa is the fraction of cultivated land in the enumeration area (EA) on which cocoa is planted. Precipitation is in meters per year, and temperature is in degrees Celsius, both historical averages taken from Hijmans et al. (2005). Standard errors, in parentheses, are clustered at the EA level. All regressions include region indicators and the primary language of the household head as controls. The sample is all households in the Ghana Living Standards Survey rounds 1 and 2 (1987-89) that owned agricultural land. HH Exp = household expenditure per capita.

* Significant at the .05 level.

$* *$ Significant at the .01 level.

land. However, this estimate is plagued by reverse causality and omitted-variables biases, as well as an attenuation bias due to measurement error.

I turn now to instrumental variables (IV) estimates that address these endogeneity problems. Column 2 shows the result for the reduced-form regression of the right to rent out land on the cocoa suitability index. The coefficient is .11 and is statistically significant. This implies that moving from an area completely unsuitable for cocoa production (CocoaSuit $=0$ ) to one very suitable (CocoaSuit $=1$ ) results in an 11-percentage-point increase in the prevalence of the right to rent out land.

Column 3 shows the IV estimate of the effect of cocoa cultivation on the right to rent out land, for which cocoa cultivation is instrumented for by using cocoa suitability, which at .698 is similar in magnitude to the OLS estimate and is statistically significant.

Table 9 similarly presents the OLS, reduced-form, and IV estimates for regressions that use Right to Sell Land as the dependent variable. The results are similar to the results for Right to Rent out Land.

These data thus provide support for the hypothesis of Demsetz (1967). Areas that are suitable for cocoa were subject to a demand-side shock in the twentieth century as cocoa quickly became an important cash crop in those areas. Cocoa increased the size of the distortion caused by customary property rights institutions, which generated demand for more individualized property rights insti- 
Table 8

Effect of Cocoa Cultivation on the Right to Rent out Land

\begin{tabular}{|c|c|c|c|c|c|c|}
\hline & $\begin{array}{l}\text { OLS } \\
(1)\end{array}$ & $\begin{array}{l}\text { OLS } \\
(2)\end{array}$ & $\begin{array}{l}\text { IV } \\
(3)\end{array}$ & $\begin{array}{l}\text { OLS } \\
(4)\end{array}$ & $\begin{array}{l}\text { OLS } \\
(5)\end{array}$ & $\begin{array}{l}\text { IV } \\
(6)\end{array}$ \\
\hline FracCocoa $_{v}$ & $\begin{array}{l}.590^{* *} \\
(.136)\end{array}$ & & $\begin{array}{c}.698^{*} \\
(.287)\end{array}$ & $\begin{array}{l}.675^{\star *} \\
(.144)\end{array}$ & & $\begin{array}{l}1.00^{\star} \\
(.399)\end{array}$ \\
\hline CocoaSuit $_{v}$ & & $\begin{array}{l}.114^{\star} \\
(.0481)\end{array}$ & & & $\begin{array}{l}.132^{\star *} \\
(.0507)\end{array}$ & \\
\hline Temperature & & & & $\begin{array}{r}-.0370^{+} \\
(.0216)\end{array}$ & $\begin{array}{r}-.0255 \\
(.0211)\end{array}$ & $\begin{array}{r}-.0450^{+} \\
(.0234)\end{array}$ \\
\hline Temperature $^{2}$ & & & & $\begin{array}{r}-.000103^{\star *} \\
(.0000362)\end{array}$ & $\begin{array}{r}-.0000913^{\star} \\
(.0000376)\end{array}$ & $\begin{array}{r}-.000114^{\star \star} \\
(.0000376)\end{array}$ \\
\hline Precipitation & & & & $\begin{array}{r}-1.43^{\star} \\
(.593)\end{array}$ & $\begin{array}{r}-1.38^{\star} \\
(.638)\end{array}$ & $\begin{array}{r}-1.55^{\star \star} \\
(.590)\end{array}$ \\
\hline Precipitation $^{2}$ & & & & $\begin{array}{c}.499^{*} \\
(.219)\end{array}$ & $\begin{array}{c}.503^{\star} \\
(.238)\end{array}$ & $\begin{array}{c}.514^{*} \\
(.212)\end{array}$ \\
\hline Constant & $\begin{array}{c}.361^{\star *} \\
(.0398)\end{array}$ & $\begin{array}{l}.372^{\star *} \\
(.0454)\end{array}$ & $\begin{array}{c}.372^{\star *} \\
(.0454)\end{array}$ & $\begin{array}{l}2.39^{\star *} \\
(.711)\end{array}$ & $\begin{array}{l}2.02^{\star *} \\
(.717)\end{array}$ & $\begin{array}{l}2.68^{\star *} \\
(.779)\end{array}$ \\
\hline$R^{2}$ & .0824 & .0712 & .0819 & .0877 & .0749 & .0838 \\
\hline
\end{tabular}

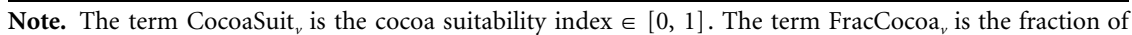
cultivated land in the enumeration area (EA) on which cocoa is planted. Precipitation is in meters per year, and temperature is in degrees Celsius, both historical averages taken from Hijmans et al. (2005). For the results in columns 3 and 6, FracCocoa ${ }_{v}$ is instrumented by CocoaSuit $v^{.}$Standard errors, in parentheses, are clustered at the EA level. All regressions include region indicators and the primary language of the household head as controls. The sample is all households in the Ghana Living Standards Survey rounds 1 and 2 (1987-89) that owned agricultural land. OLS = ordinary least squares; IV = instrumental variables. $N=2,803$.

+ Significant at the .10 level.

* Significant at the .05 level.

** Significant at the .01 level.

tutions. That demand induced changes in property rights institutions, which are reflected in the greater prevalence of transfer rights in cocoa-growing areas.

\subsubsection{Robustness Check: Adding Controls for Climate}

One obvious concern about the exclusion restriction assumption is that cocoa suitability may also proxy for other geographic variables that affect property rights through other channels. Many of these alternative channels are also Demsetzian-geography affects the production function available in ways that change the net benefits of more individualized property rights institutions. Moreover, my inclusion of region fixed effects helps control for some of this geographic variation. Nonetheless, I add controls for local climate-quadratic polynomials in average annual temperature and precipitation-as a robustness check. Climate data are taken from Hijmans et al. (2005). If the baseline results are driven by such an exclusion restriction violation rather than a causal effect of cocoa production, then adding controls for climate should reduce the size of my IV estimates.

The results in columns 4-6 of Table 7 reproduce my first-stage results including controls for climate. Adding these controls decreases the partial correlation of 
Table 9

Effect of Cocoa Cultivation on the Right to Sell Land

\begin{tabular}{|c|c|c|c|c|c|c|}
\hline & $\begin{array}{l}\text { OLS } \\
(1)\end{array}$ & $\begin{array}{l}\text { OLS } \\
(2)\end{array}$ & $\begin{array}{l}\text { IV } \\
(3)\end{array}$ & $\begin{array}{l}\text { OLS } \\
(4)\end{array}$ & $\begin{array}{l}\text { OLS } \\
(5)\end{array}$ & $\begin{array}{l}\text { IV } \\
(6)\end{array}$ \\
\hline FracCocoa $_{v}$ & $\begin{array}{l}.335^{\star *} \\
(.112)\end{array}$ & & $\begin{array}{c}.692^{\star} \\
(.310)\end{array}$ & $\begin{array}{l}.354^{* *} \\
(.119)\end{array}$ & & $\begin{array}{c}.867^{+} \\
(.454)\end{array}$ \\
\hline CocoaSuit $_{v}$ & & $\begin{array}{c}.109^{*} \\
(.0469)\end{array}$ & & & $\begin{array}{c}.110^{*} \\
(.0535)\end{array}$ & \\
\hline Temperature & & & & $\begin{array}{c}-.0347 \\
(.0214)\end{array}$ & $\begin{array}{c}-.0300 \\
(.0192)\end{array}$ & $\begin{array}{r}-.0472^{\star} \\
(.0218)\end{array}$ \\
\hline Temperature $^{2}$ & & & & $\begin{array}{r}-.0000735^{\star} \\
(.0000323)\end{array}$ & $\begin{array}{r}-.0000708^{\star} \\
(.0000317)\end{array}$ & $\begin{array}{c}-.0000893^{\star \star} \\
(.0000338)\end{array}$ \\
\hline Precipitation & & & & $\begin{array}{r}-.752 \\
(.485)\end{array}$ & $\begin{array}{c}-.793 \\
(.508)\end{array}$ & $\begin{array}{r}-.907^{+} \\
(.523)\end{array}$ \\
\hline Precipitation $^{2}$ & & & & $\begin{array}{c}.298 \\
(.190)\end{array}$ & $\begin{array}{l}.315 \\
(.194)\end{array}$ & $\begin{array}{l}.310 \\
(.201)\end{array}$ \\
\hline Constant & $\begin{array}{l}.232^{* *} \\
(.0322)\end{array}$ & $\begin{array}{l}.207^{\star *} \\
(.0438)\end{array}$ & $\begin{array}{l}.177^{\star *} \\
(.0542)\end{array}$ & $\begin{array}{l}1.63^{*} \\
(.679)\end{array}$ & $\begin{array}{l}1.51^{*} \\
(.635)\end{array}$ & $\begin{array}{l}2.08^{\star *} \\
(.708)\end{array}$ \\
\hline$R^{2}$ & .116 & .113 & .108 & .120 & .117 & .107 \\
\hline
\end{tabular}

Note. The term CocoaSuit ${ }_{v}$ is the cocoa suitability index $\in[0,1]$. The term FracCocoa $_{v}$ is the fraction of cultivated land in the enumeration area (EA) on which cocoa is planted. Precipitation is in meters per year, and temperature is in degrees Celsius, both historical averages taken from Hijmans et al. (2005). For the results in columns 3 and 6, FracCocoa ${ }_{v}$ is instrumented by CocoaSuit $v^{.}$Standard errors, in parentheses, are clustered at the EA level. All regressions include region indicators and the primary language of the household head as controls. The sample is all households in the Ghana Living Standards Survey rounds 1 and 2 (1987-89) that owned agricultural land. OLS = ordinary least squares; IV = instrumental variables. $N=2,705$.

+ Significant at the .10 level.

* Significant at the .05 level.

** Significant at the .01 level.

cocoa suitability and the fraction of land planted in cocoa, as one would expect since temperature and precipitation are part of cocoa suitability, but the results are qualitatively similar.

Columns 4-6 of Tables 8 and 9 redo the analysis of the effect of cocoa on property rights including these climate controls. The results are largely the same, with both the reduced-form and IV estimates in columns 5 and 6, respectively, now somewhat larger, which gives greater confidence that the cocoa suitability instrument is isolating a causal effect of cocoa instead of picking up the effect of a different geographic channel.

\section{Conclusion}

Ghana and Côte d'Ivoire's very different de jure laws on property in land have had little effect on de facto property rights institutions. In contrast, the economic needs of communities, as proxied for by cocoa cultivation, have had an impact on the degree of individualization of property rights in land. My work contributes to a growing literature that points to nonstate sources of norms as 
important components of property rights institutions and suggests that these norms do, to some extent, evolve to accommodate the changing needs of society.

While I find little effect of the differing state policies and de jure laws on de facto institutions in Ghana and Côte d'Ivoire, sometimes formal law does have an effect on property rights. For example, La Ferrara and Milazzo (2012) find that the 1985 Intestate Succession Law in Ghana had an impact on inheritance practices. In particular, the authors document a shift away from investment in boys' human capital among matrilineal groups under the law, which they interpret as due to fathers' substituting toward land inheritance and away from investing in their sons' human capital in response to the law. Explaining when and why formal law can influence customary property norms is an important topic for future research.

\section{Appendix}

\section{Data}

\section{Côte d'Ivoire Living Standards Survey}

The CILSS was run for 4 years from 1985 to 1988 as a rotating panel. In each year, half of the households from the previous year's survey were replaced with new households. The sampling was done in two stages: first, EAs were selected from a census list with a probability proportional to the population, and then households were sampled within each EA. I use just the first observation for each household, discarding any data on the household from subsequent years. The resulting survey data set has a total of 200 EAs and 4,351 households.

While the sampling design was intended to produce a self-weighted sample, analysis of the sample revealed several biases in the sampling process, including an oversampling of wealthier households. ${ }^{9}$ Corrective weights are provided with the data set, and I use these weights (allweightn) in my analysis.

\section{Ghana Living Standards Survey Rounds 1 and 2}

The GLSS rounds 1 and 2 were run in 1987-88 and 1988-89, respectively, as a rotating panel with a two-stage sampling design. I retain only data from the first visit for each household, discarding revisits in subsequent years. The resulting survey sample has 261 EAs and 4,826 households.

\footnotetext{
${ }^{9}$ For example, for 1985 and 1986, a full enumeration of households within each selected enumeration area was not done; instead, a sampling frame was generated by selecting the $n$th door in each enumeration area, beginning from some central location. This leads to an oversampling of households with multiple doors. The weights I use incorporate the weights constructed by Demery and Grootaert (1993) to correct for the resulting sampling bias.
} 


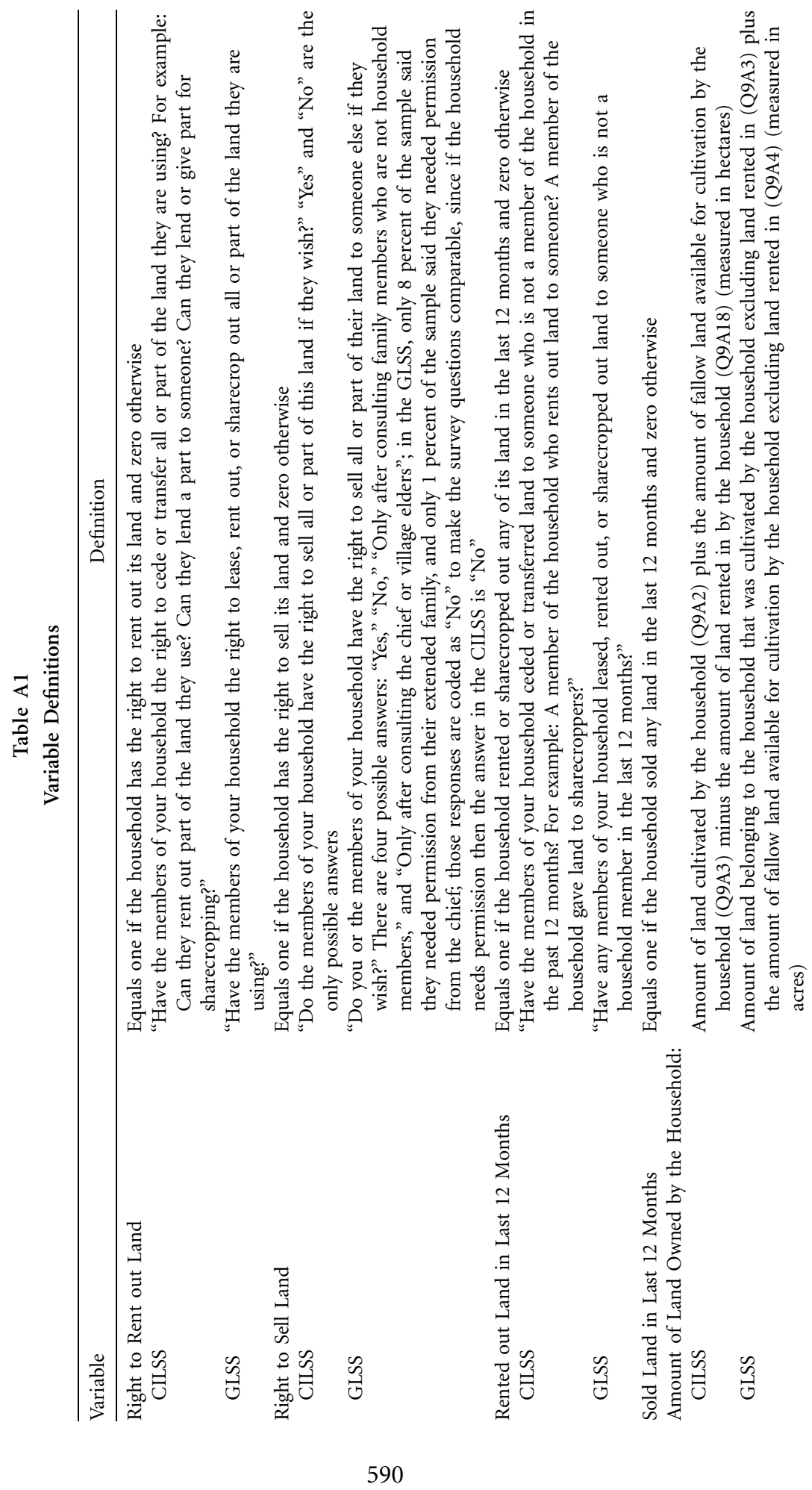




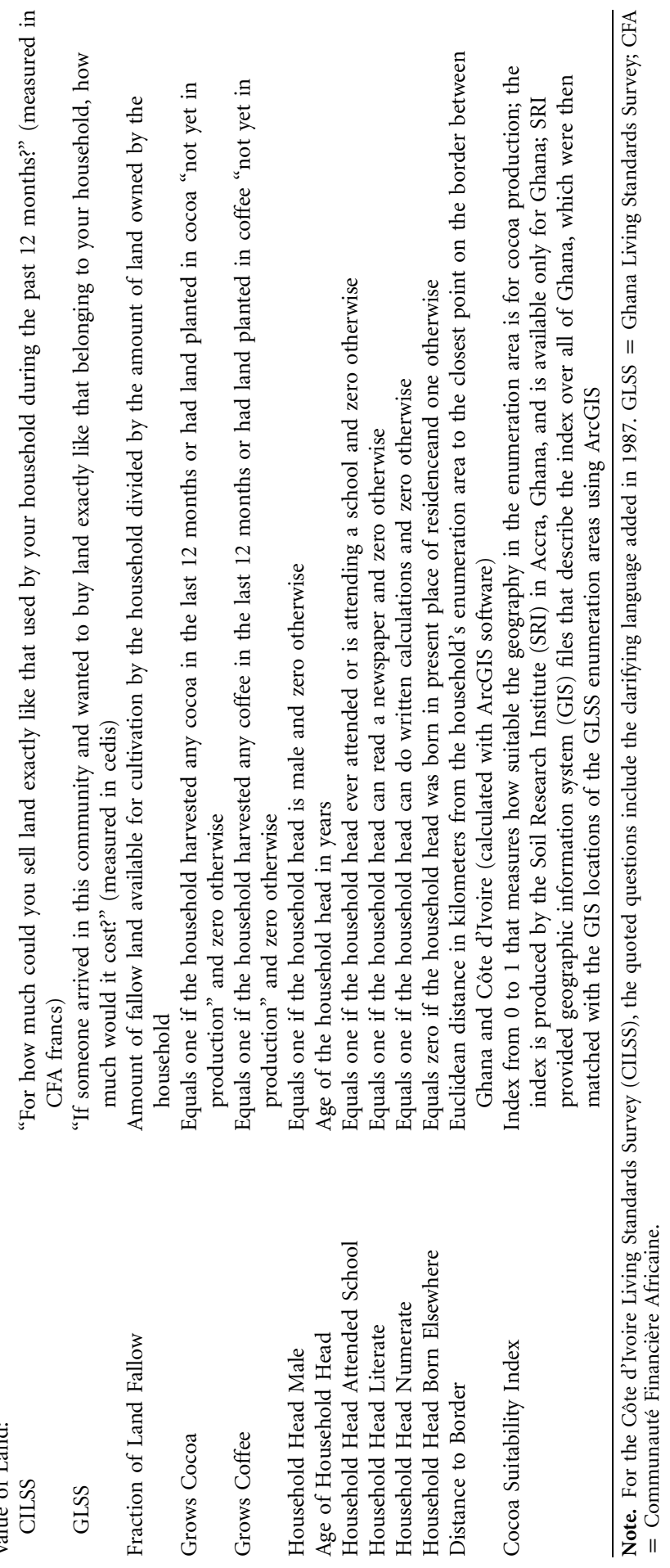




\section{References}

Acemoglu, Daron, Simon Johnson, and James A. Robinson. 2001. The Colonial Origins of Comparative Development: An Empirical Investigation. American Economic Review 91:1369-1401.

$\rightarrow$ Aldashev, Gani, Imane Chaara, Jean-Philippe Platteau, and Zaki Wahhaj. 2012. Using the Law to Change Custom. Journal of Development Economics 97:182-200.

$\rightarrow$ Asante, Samuel K. B. 1964. Interests in Land in the Customary Law of Ghana-a New Appraisal. Yale Law Journal 74:848-85.

$\rightarrow$ Ault, David E., and Gilbert L. Rutman. 1979. The Development of Individual Rights to Property in Tribal Africa. Journal of Law and Economics 22:163-82.

Austin, Gareth. 2004. Labour, Land, and Capital in Ghana: From Slavery to Free Labour in Asante, 1807-1956. Rochester, N.Y.: University of Rochester Press.

Barbour, K. M. 1962. A Geographical Analysis of Boundaries in Inter-tropical Africa. Pp. 303-23 in Essays on African Population, edited by K. M. Barbour and R. Mansell Prothero. New York: Praeger.

Bates, Robert H. 1984. Markets and States in Tropical Africa. Berkeley: University of California Press.

$\rightarrow$ Benavot, Aaron, and Phyllis Riddle. 1988. The Expansion of Primary Education, 18701940: Trends and Issues. Sociology of Education 61:191-210.

Berger, Daniel. 2009. Taxes, Institutions, and Local Governance: Evidence from a Natural Experiment in Colonial Nigeria. Unpublished manuscript. New York University, Department of Politics, New York.

Berry, Sara. 2000. Chiefs Know Their Boundaries: Essays on Property, Power, and the Past in Asante, 1896-1996. Portsmouth: Heinemann.

$\rightarrow$ Besley, Timothy. 1995. Property Rights and Investment Incentives: Theory and Evidence from Ghana. Journal of Political Economy 103:903-37.

$\rightarrow$ Boone, Catherine. 2007. Property and Constitutional Order: Land Tenure Reform and the Future of the African State. African Affairs 106:557-86.

Boserup, Ester. 1965. The Conditions of Agricultural Growth: The Economics of Agrarian Change under Population Pressure. Chicago: Aldine.

Brownlie, Ian. 1979. African Boundaries: A Legal and Diplomatic Encyclopaedia. London: C. Hurst.

Bruce, John W. 1988. A Perspective on Indigenous Land Tenure Systems and Land Concentration. Pp. 23-52 in Land Concentration in Africa, edited by R. E. Downs and Stephen P. Reyna. Lebanon, N.H.: University Press of New England.

Busia, Kofi A. 1951. The Position of the Chief in the Modern Political System of Ashanti: A Study of the Influence of Contemporary Social Changes on Ashanti Political Institutions. London: Oxford University Press for the International African Institute.

$\rightarrow$ Chauveau, Jean-Pierre, and Jean-Philippe Colin. 2010. Customary Transfers and Land Sales in Côte d'Ivoire: Revisiting the Embeddedness Issue. Africa 80:81-103.

Cogneau, Denis, Sandrine Mesple-Somps, and Gilles Spielvogel. 2012. Development at the Border: A Study of National Integration in Post-colonial West Africa. Working paper. Développement, Institutions et Mondialisation, Paris.

Cogneau, Denis, and Alexander Moradi. 2011. Borders That Divide: Education and Religion in Ghana and Togo since Colonial Times. Working Paper Series 2911. University of Sussex, Department of Economics, Brighton. 
$\rightarrow$ Conley, Timothy G. 1999. GMM Estimation with Cross Sectional Dependence. Journal of Econometrics 92:1-45.

Crook, Richard, Simplice Affou, Daniel Hammond, Adja F. Vanga, and Mark OwusuYeboah. 2007. Law, Legal Institutions, and the Protection of Land Rights in Ghana and Cote d'lvoire: Developing a More Effective and Equitable System. Institute of Development Studies Research Report No. 58. Institute of Development Studies, Brighton.

$\rightarrow$ Crowder, Michael. 1964. Indirect Rule-French and British Style. Africa: Journal of the International African Institute 340:197-205.

$\rightarrow$ Demery, Lionel, and Christiaan Grootaert. 1993. Correcting for Sampling Errors in the Measurement of Welfare and Poverty: The Case of the Côte d'Ivoire Living Standards Survey. World Bank Economic Review 7:263-92.

$\rightarrow$ Demsetz, Harold. 1967. Toward a Theory of Property Rights. American Economic Review 57:347-59.

$\rightarrow$ Due, Jean M. 1969. Agricultural Development in the Ivory Coast and Ghana. Journal of Modern African Studies 7:637-60.

$\rightarrow$ Easterly, William. 2008. Institutions: Top down or Bottom up? American Economic Review 98:95-99.

$\rightarrow$ Easterly, William, and Ross Levine. 1997. Africa's Growth Tragedy: Policies and Ethnic Divisions. Quarterly Journal of Economics 112:1203-50.

Ellickson, Robert C. 1991. Order without Law: How Neighbors Settle Disputes. Cambridge, Mass.: Harvard University Press.

Fan, Jianqing, and Irene Gijbels. 1996. Local Polynomial Modelling and Its Applications. London: Chapman \& Hall.

Fenske, James. 2012. Land Abundance and Economic Institutions: Egba Land and Slavery, 1830-1914. Economic History Review 65:527-55.

Firmin-Sellers, Kathryn. 1996. The Transformation of Property Rights in the Gold Coast: An Empirical Analysis Applying Rational Choice Theory. Cambridge: Cambridge University Press.

$\rightarrow$. 2000. Institutions, Context, and Outcomes: Explaining French and British Rule in West Africa. Comparative Politics 32:253-72.

$\rightarrow$ Goldstein, Marcus, and Christopher Udry. 2008. The Profits of Power: Land Rights and Agricultural Investment in Ghana. Journal of Political Economy 116:981-1022.

Griffith, Sir William Bradford. 1898. Ordinances of the Gold Coast Colony. 2 vols. London: Stevens \& Sons, Ltd.

Hailey, William M. 1957. An African Survey. New York: Oxford University Press.

Heath, John R. 1993. Land Rights in Cote d'Ivoire: Survey and Prospects for Project Intervention. World Bank Technical Paper No. 238. Washington, D.C.: World Bank.

Herbst, Jeffrey Ira. 2000. States and Power in Africa: Comparative Lessons in Authority and Control. Princeton, N.J.: Princeton University Press.

$\rightarrow$ Hijmans, Robert J., Susan E. Cameron, Juan L. Parra, Peter G. Jones, and Andy Jarvis. 2005. Very High Resolution Interpolated Climate Surfaces for Global Land Area. International Journal of Climatology 25:1965-78.

Hill, Polly. 1963. The Migrant Cocoa-Farmers of Southern Ghana: A Study in Rural Capitalism. Cambridge: Cambridge University Press.

Hopkins, Anthony G. 1973. An Economic History of West Africa. New York: Columbia University Press.

$\rightarrow$ Imbens, Guido W., and Thomas Lemieux. 2008. Regression Discontinuity Designs: A Guide to Practice. Journal of Econometrics 142:615-35. 
La Ferrara, Eliana, and Annamaria Milazzo. 2012. Customary Norms, Inheritance, and Human Capital. Unpublished manuscript. Bocconi University, Department of Economics, Milan.

$\rightarrow$ La Porta, Rafael, Florencio Lopez-de-Silanes, and Andrei Shleifer. 2008. The Economic Consequences of Legal Origins. Journal of Economic Literature 46:285-332.

$\rightarrow$ Lee, David S., and Thomas Lemieux. 2010. Regression Discontinuity Designs in Economics. Journal of Economic Literature 48:281-355.

Lewis, W. Arthur. 1955. The Theory of Economic Growth. London: Allen \& Unwin.

$\rightarrow$ Michalopoulos, Stelios, and Elias Papaioannou. 2013. Pre-colonial Ethnic Institutions and Contemporary African Development. Econometrica 81:113-52.

$\rightarrow$ Migot-Adholla, Shem, Peter Hazell, Benoit Blarel, and Frank Place. 1991. Indigenous Land Rights Systems in Sub-Saharan Africa: A Constraint on Productivity? World Bank Economic Review 50:155-75.

$\rightarrow$ Mulligan, Casey B., and Andrei Shleifer. 2005. The Extent of the Market and the Supply of Regulation. Quarterly Journal of Economics 120:1445-73.

North, Douglass C. 1981. Structure and Change in Economic History. New York: Norton.

North, Douglass, and Robert Paul Thomas. 1973. The Rise of the Western World: A New Economic History. Cambridge: Cambridge University Press.

$\rightarrow$ Platteau, Jean-Philippe. 1996. The Evolutionary Theory of Land Rights as Applied to SubSaharan Africa: A Critical Assessment. Development and Change 27:29-86.

- 2000. Institutions, Social Norms, and Economic Development. Amsterdam: Harwood Academic.

Posner, Eric A. 2000. Law and Social Norms. Cambridge, Mass.: Harvard University Press. Rattray, Robert S. 1923. Ashanti. Oxford: Clarendon.

. 1929. Ashanti Law and Constitution. Oxford: Oxford University Press.

Suret-Canale, Jean. 1971. French Colonialism in Tropical Africa, 1900-1945. New York: Pica.

Wilks, Ivor. 1993. Forests of Gold: Essays on the Akan and the Kingdom of Asante. Athens: Ohio University Press.

Zolberg, Aristide R. 1969. One-Party Government in the Ivory Coast. Princeton, N.J.: Princeton University Press. 